\title{
一三0- 錄驗實誌雜會究研事醫堂天順
}

呆
鼠
筀
疹
療
法

ン炭 着皮等 含二小レ

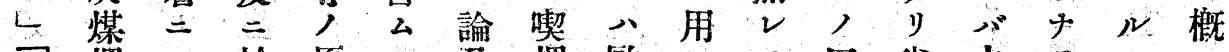
F 烟 $r$ 於原力及烟歐 $N$ 无日倘火

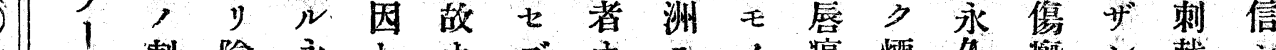

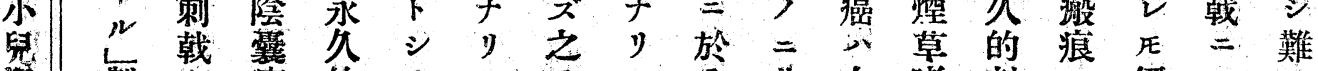

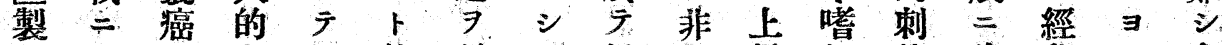

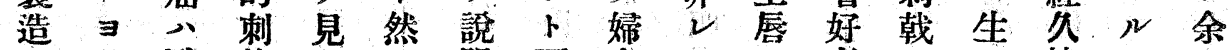

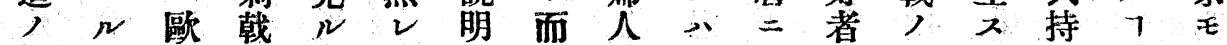

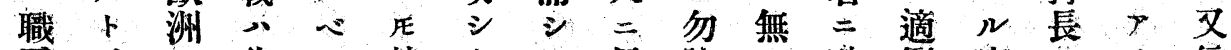

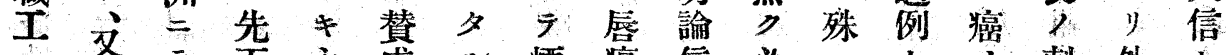

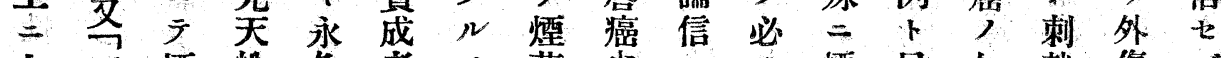
上 煙 性炎者モ草少シ え 煙目如戟傷

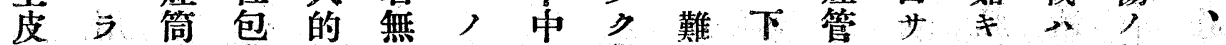

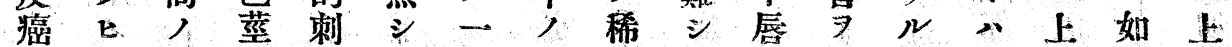

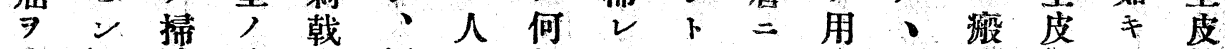

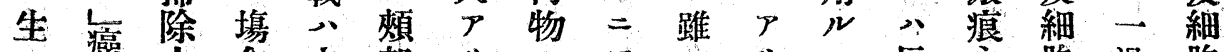

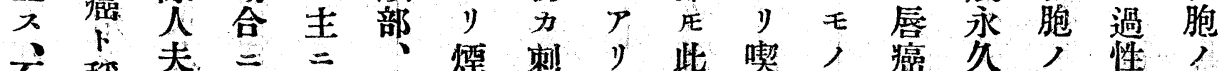

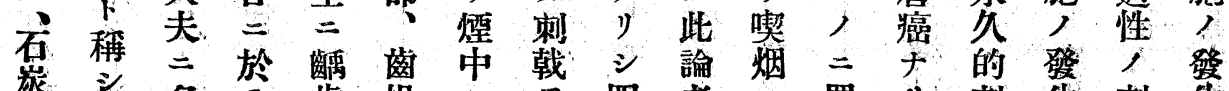

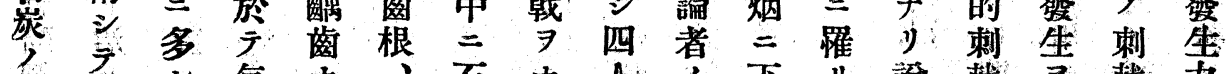
煤

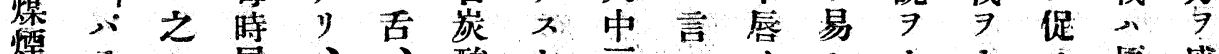

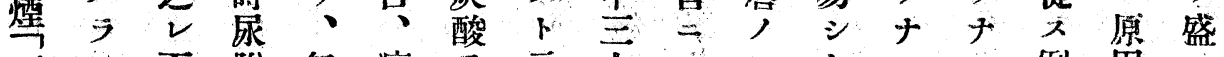
八石附包癌 $\exists$ 云人

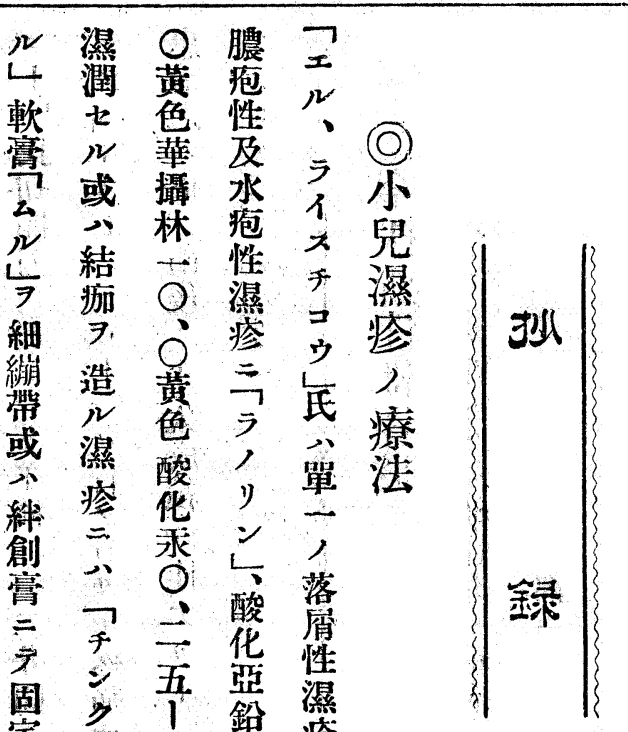

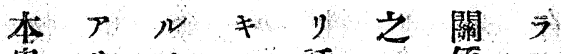

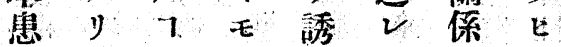

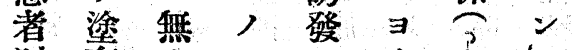

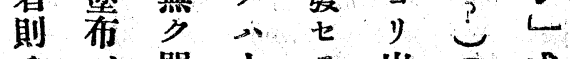
千單火 $火$ 出 $习$ 或 是系二㑺儿示 方 是條放分、タる

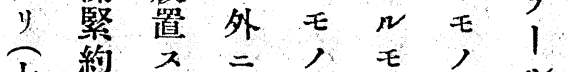

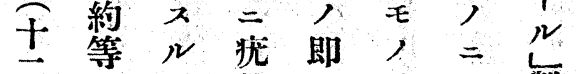

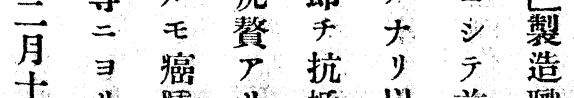
$\overrightarrow{7}$ 堃

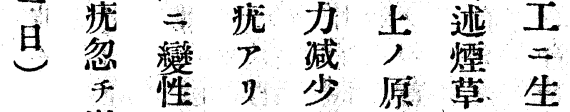
激 $大$, 因烟 怒 $N$ 之一論中 憤 7 , 例中 $;$ 起 $>$ 玩 シ 弄 厂或按 $三$ 的 酸 $卜$ 癌 一摸見戀刺癌

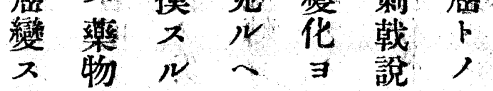


號入十四百三第誌襍會究研事醫堂天順 二严 0 -

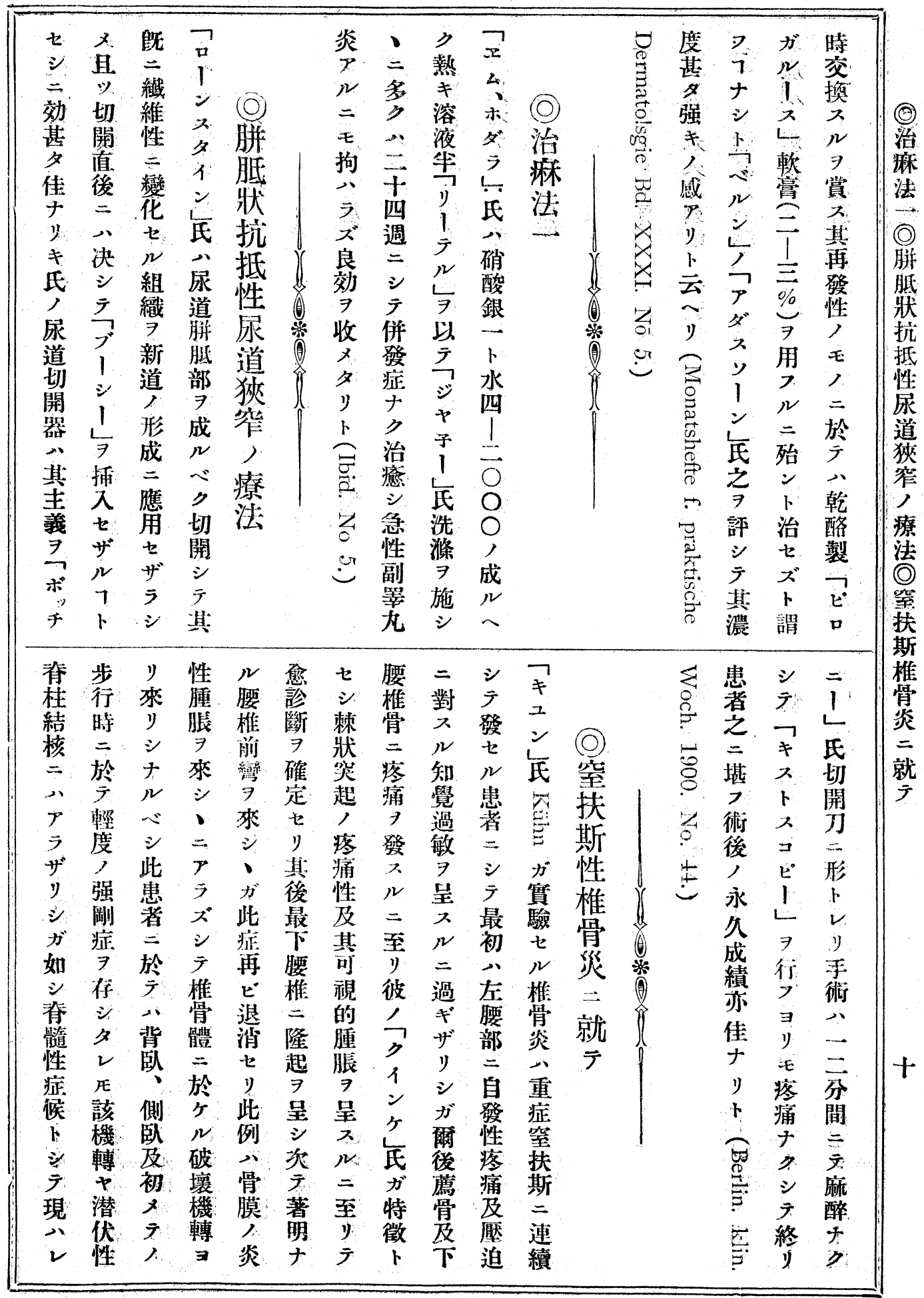


三三○一錄抄誌雜會究研事醫堂天順

()

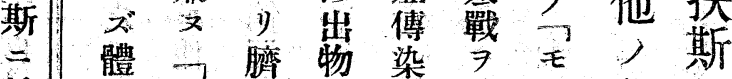

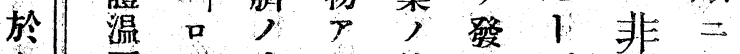

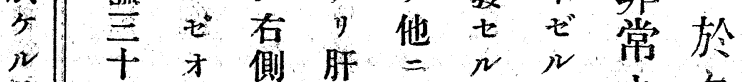

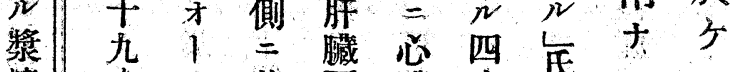

\section{(}

蟣

藮

性

㙏

盟

层

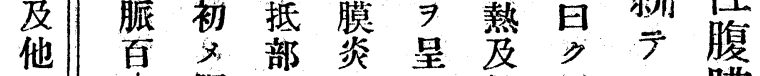

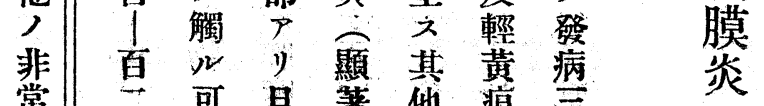

$\Xi=$ 扶儿在扶

恢斯门学斯 復, $\rightarrow$ 刃 腱 期經以上少上

$P=$ 過 $\bar{~}$ 本 射 $\sum \infty$ 徭窒 + 早

特 扶 》三 增

空 三 斯 但 $カ$ 進

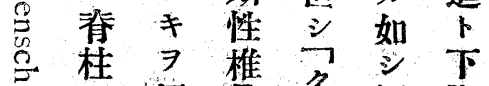

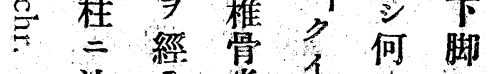

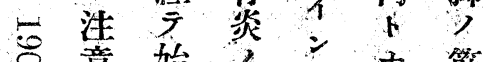
8意始人。于筋

$\bar{z} z 又$ 特 $匚$ ᄂ 瘘

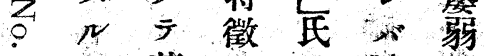

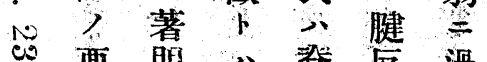

要奛

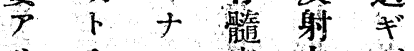

y+七症 克

卜 ル y 候進》

云 7 椎 会

子管消 久

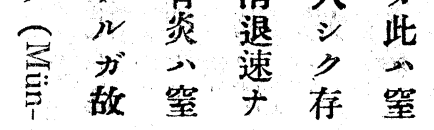

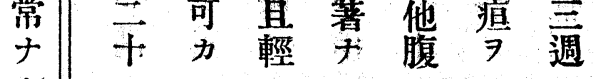

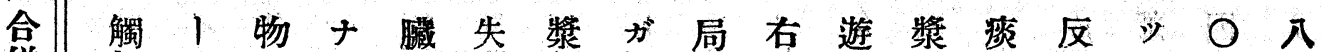

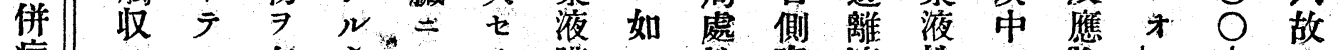

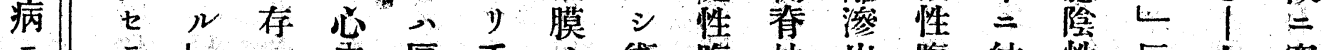

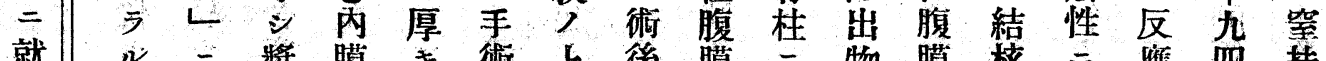

就 $v=$ 獎膜 $\neq$ 術上後膜三物膜核二應四扶 至液䈋䄉,

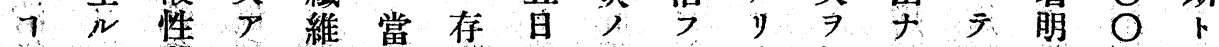
$>7$ 若 9 性 時 $t=$ 疼 5 万起

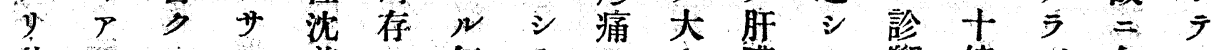

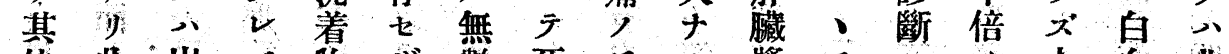

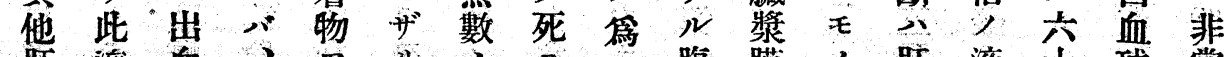

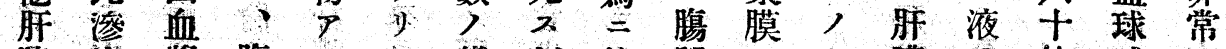

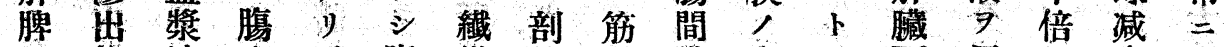

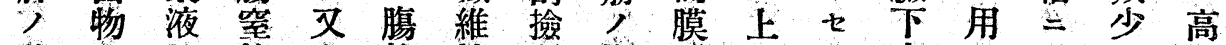
獎 $>$ 性扶定管性 2 緊腺 $=y$ 方>稀症 $\neq$ 膜

+ 北

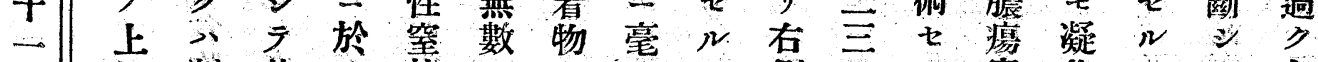

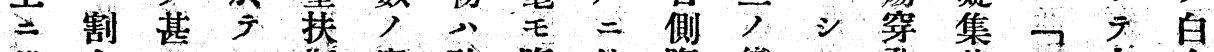

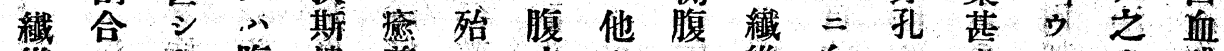

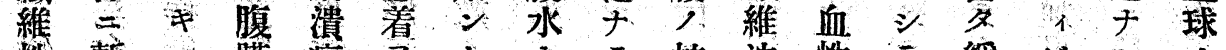

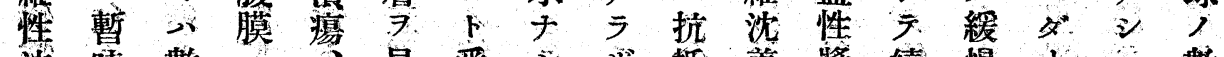

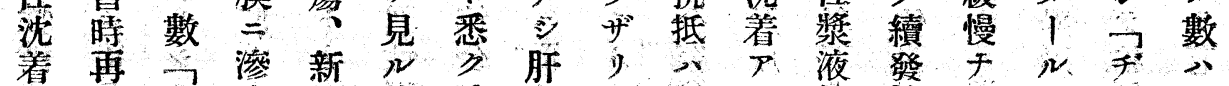

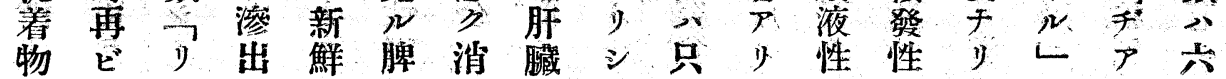


號八十四百三第誌雜會焭研事醫堂天順 四三0一

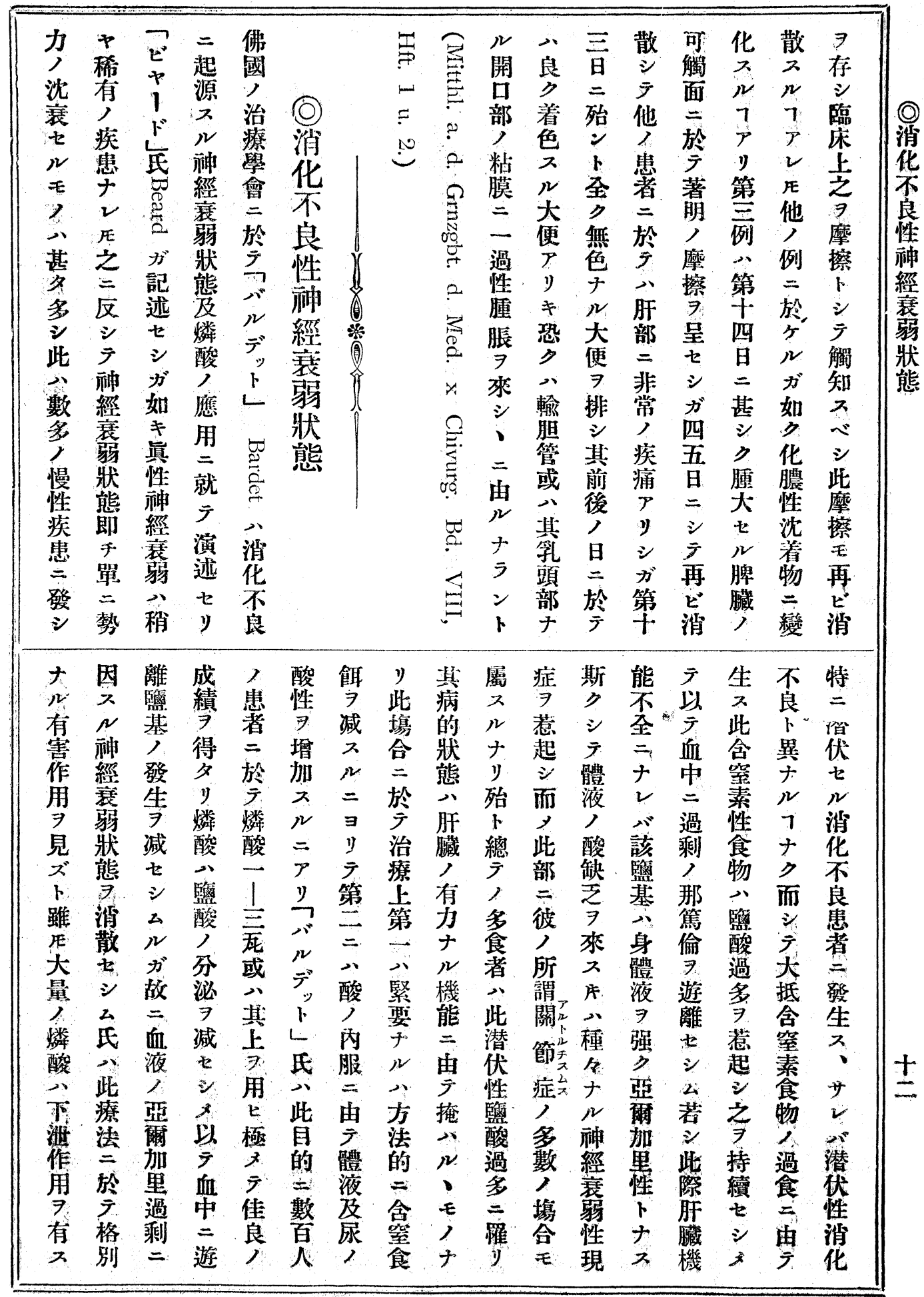


五三0- 錄抄誌雜會㶢研事醫堂天順

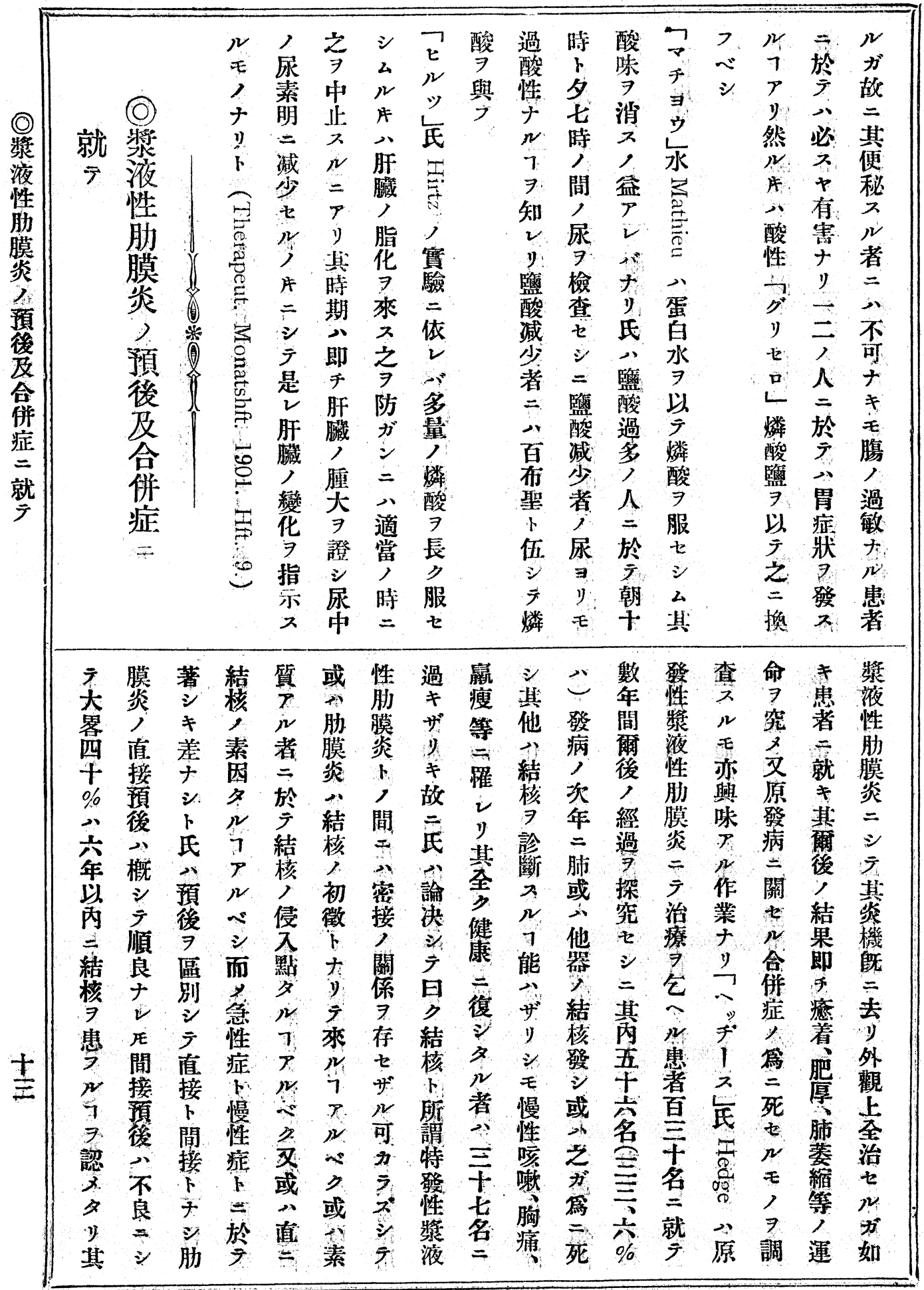




\section{號入十四百三第誌雜會究研事醫堂天順 六三0一}

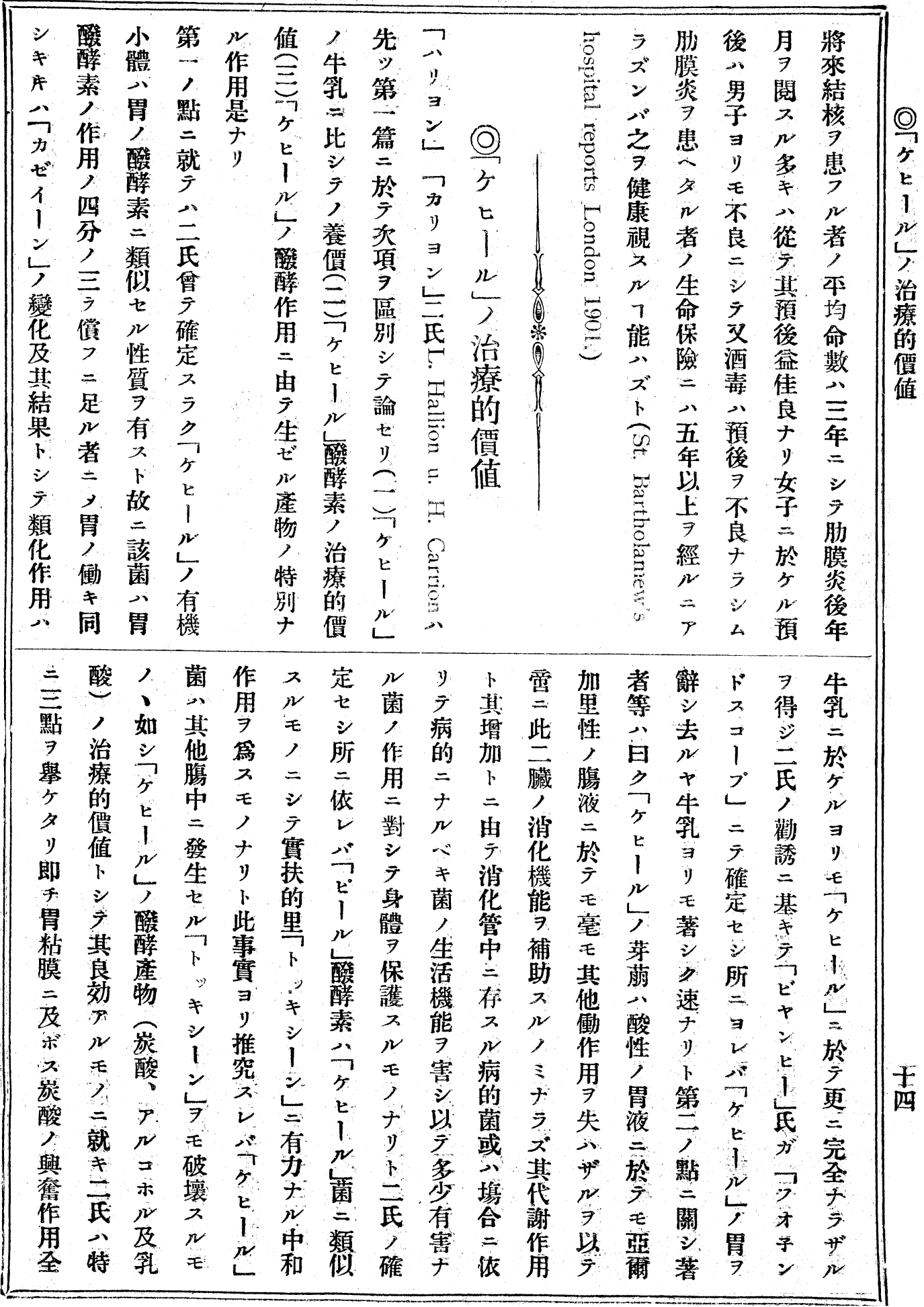


七三0- 錄抄誌㗎會究研事醫堂天順

項作 $心$ 身分胃

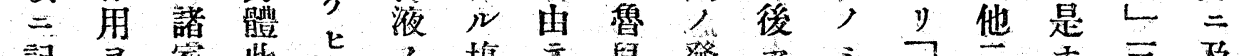

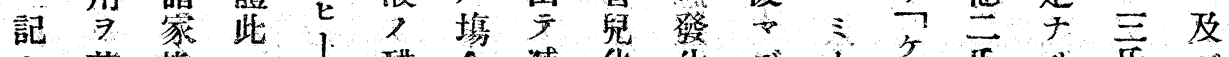

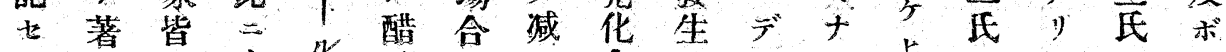
$\sim$ 至 由

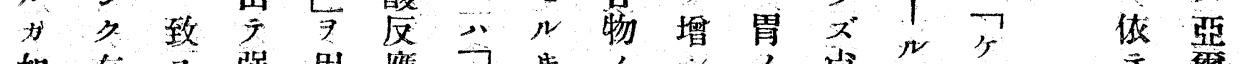

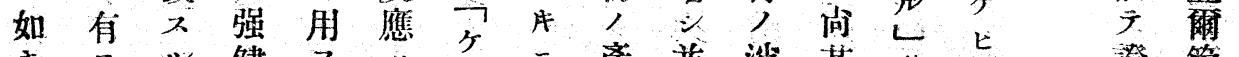
₹ ～

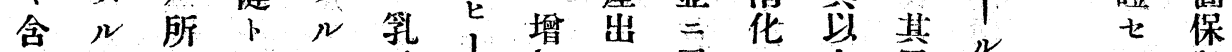

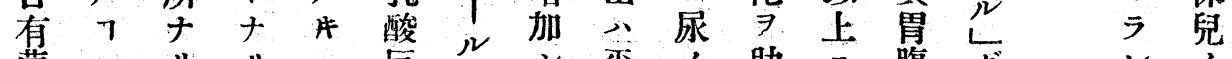

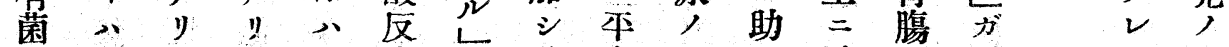
及, 其々 其全應学其常格名及中種方興

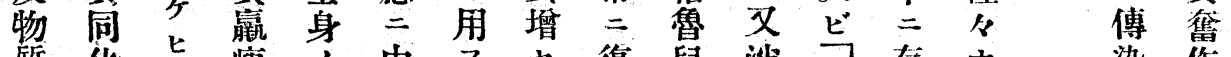
質华 1 瘦, 由于七復兒消引存

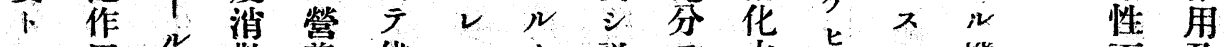

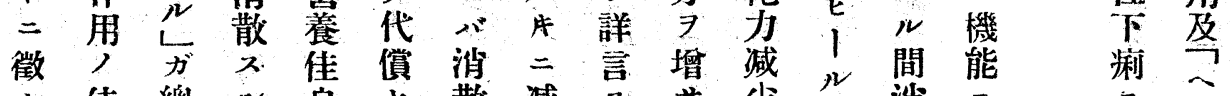

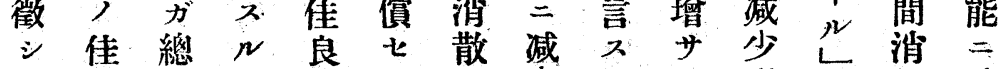

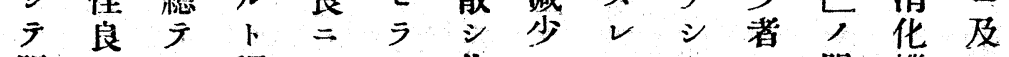

明ナ人謂ナル此ス六么二服機禾

$ナ ル$ 此 $>y$ 、際又其其於角轉

?. 1 等 點 琵了時 酸 病 他 $\overline{7}=$ 作 睄, $=$ 弱 $>$ 性的有遊止作用

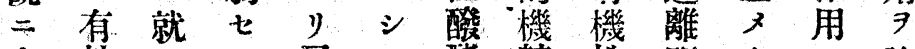

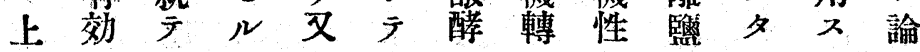
度 1 ホ台

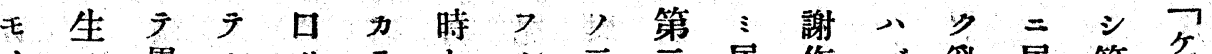

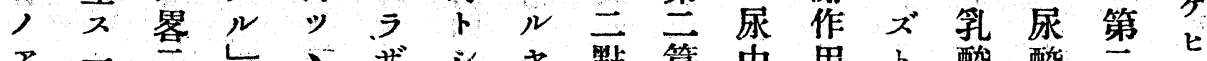

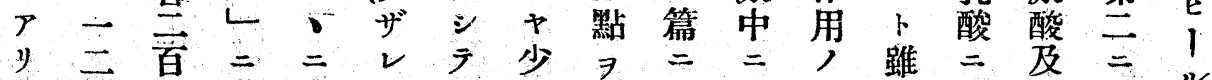

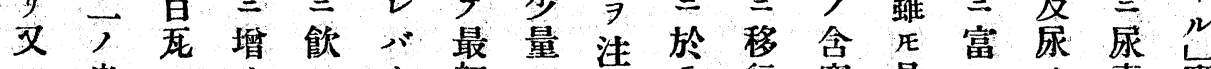

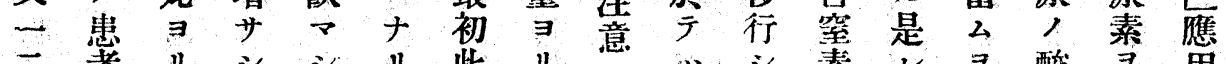

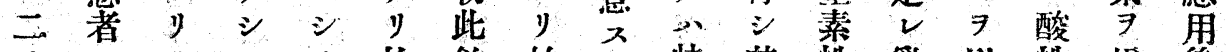

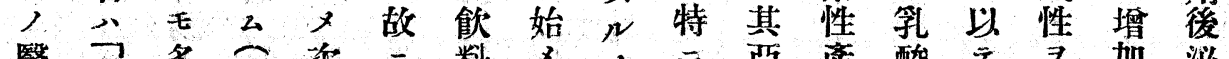
醫 $\overrightarrow{5}$ 多 $=$ 次 $=$ 料 $x,=$ 亞 產 酸 $\overline{7}$ 加 泌 師 5 力

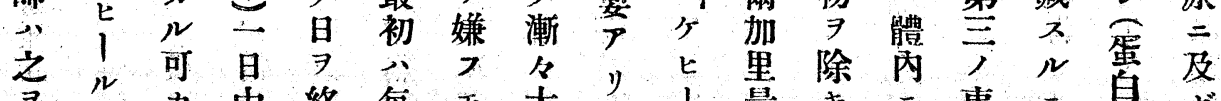

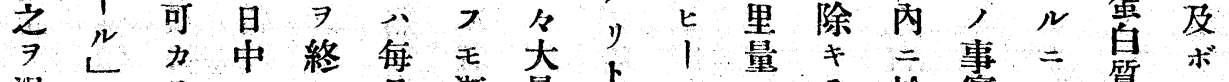

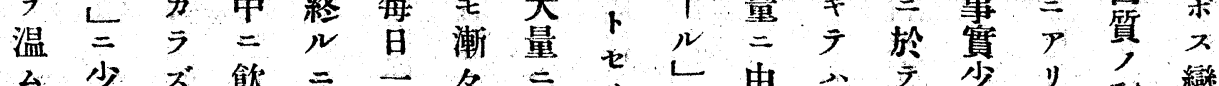

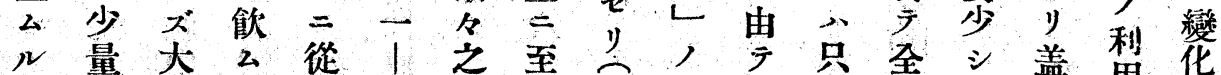

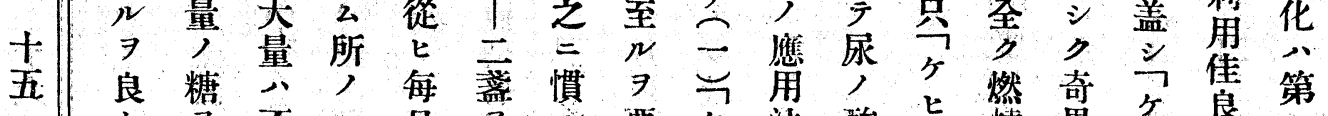
上

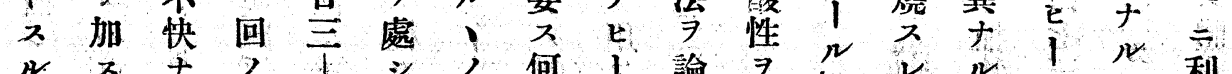

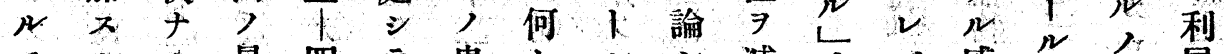

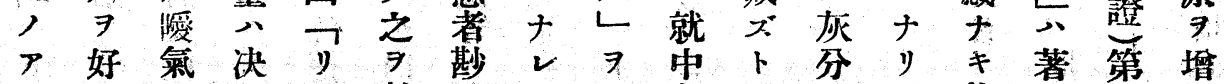

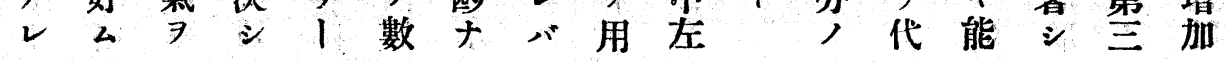


號成十四百三第誌雜會究研事醫堂天順 公三0-

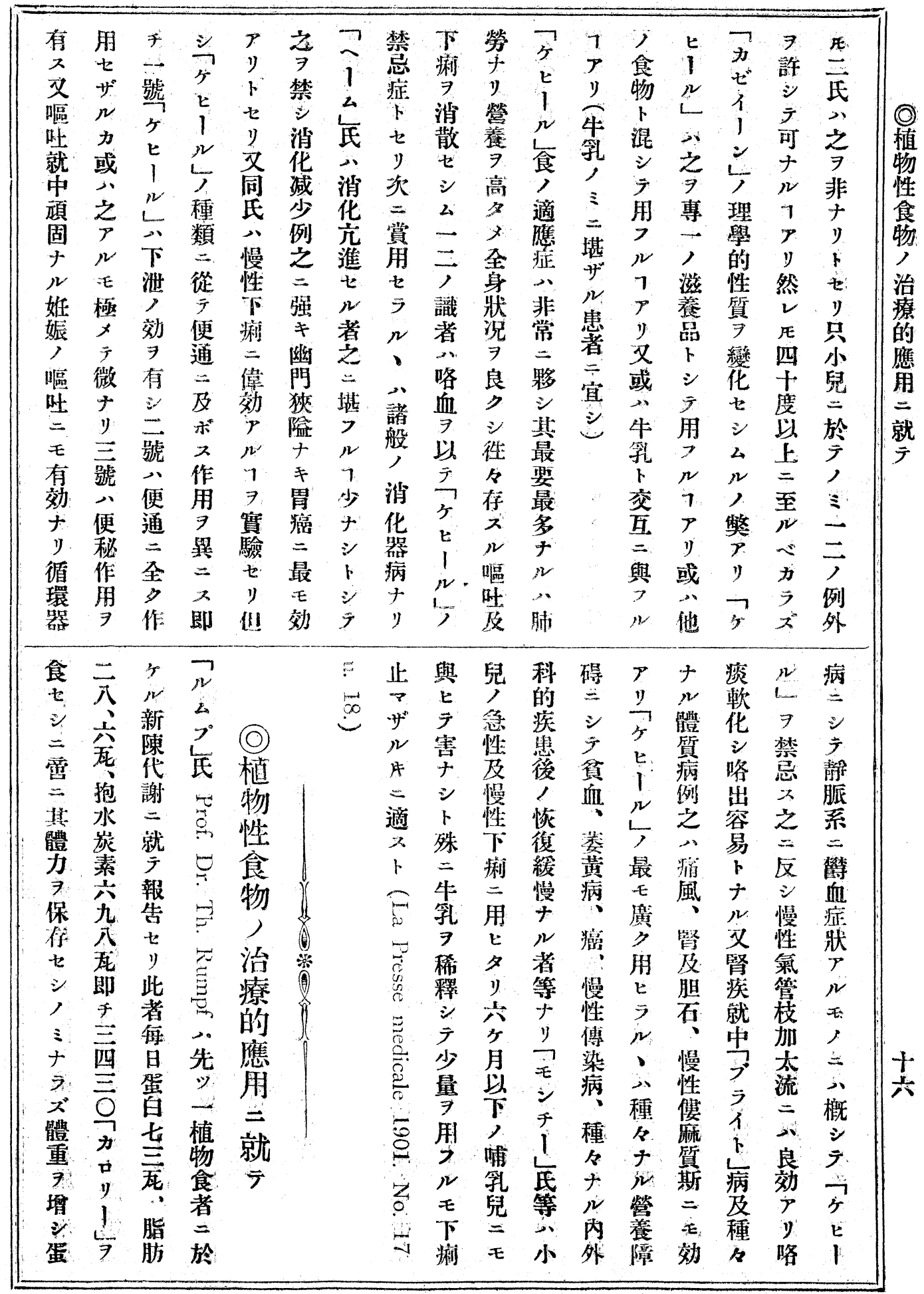




\section{九三O- 錄抄誌雜會究研事醫堂天順}

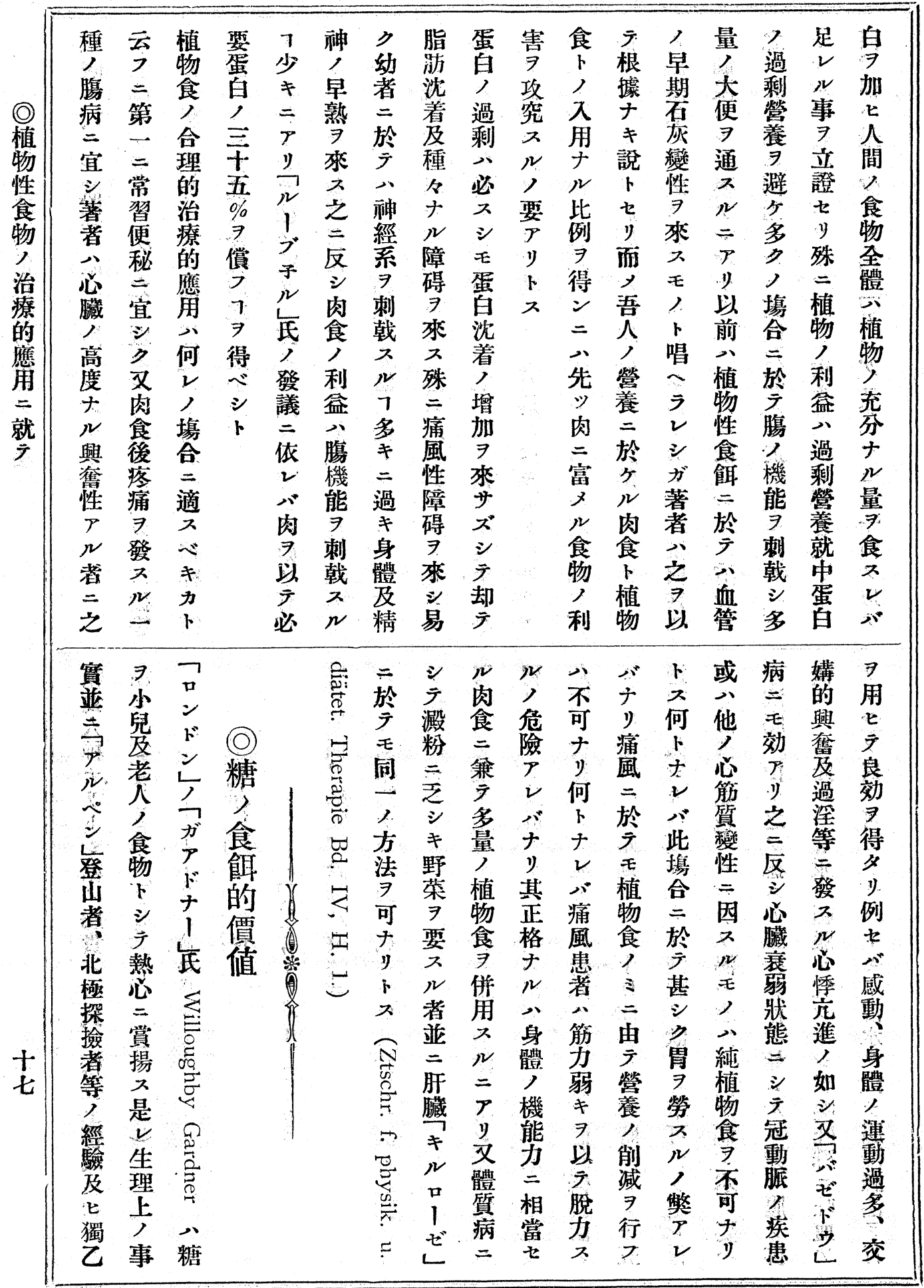


號八十四百三第誌雜會究研事醫堂天順 ○四○一

西子之 $\exists E$ 由二兒得加, 上小二八反軍

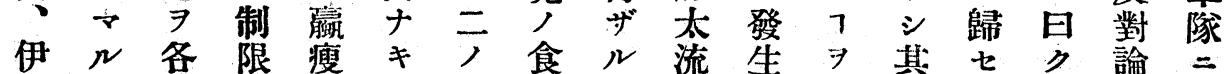

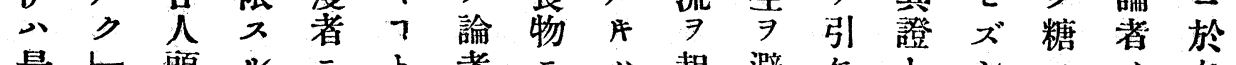

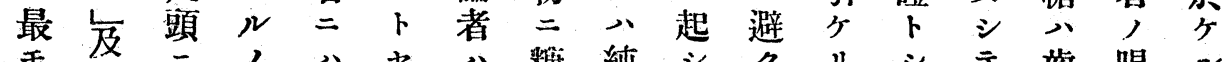

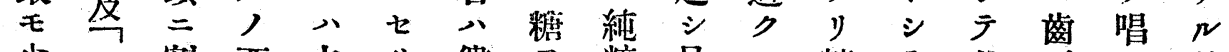

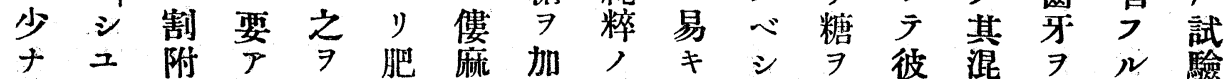

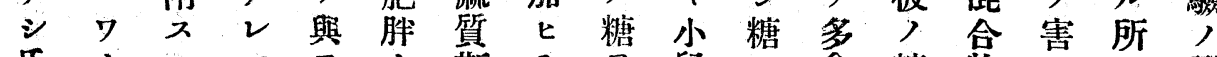

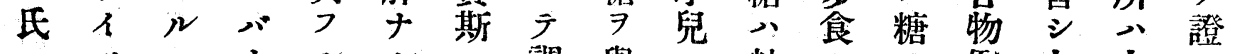

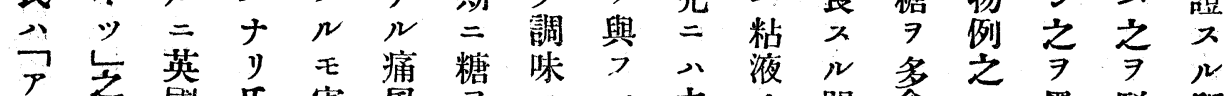

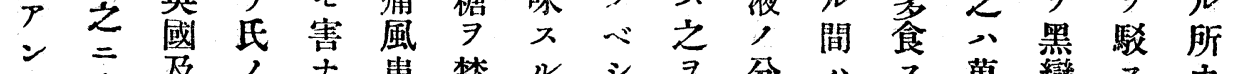

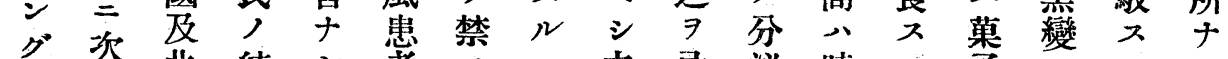

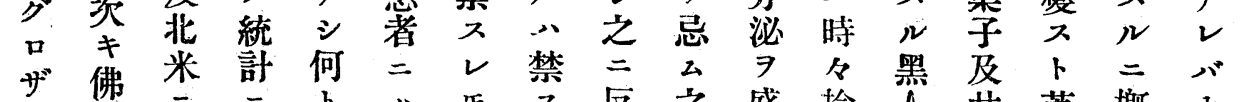

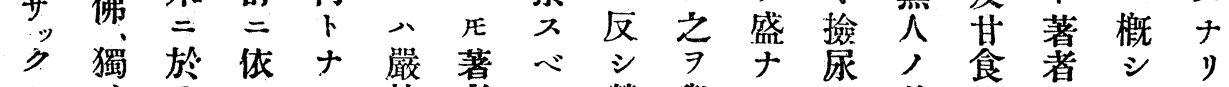

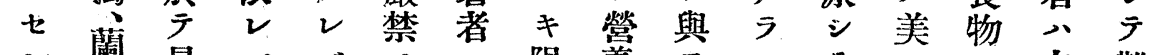

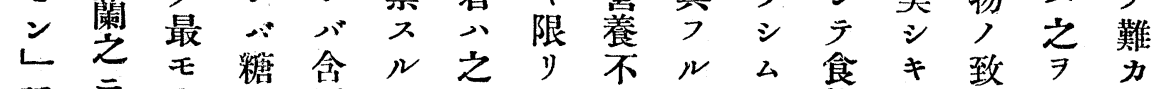
種次多, 蛋 $尹 \exists=$ 良, 心物苳入純

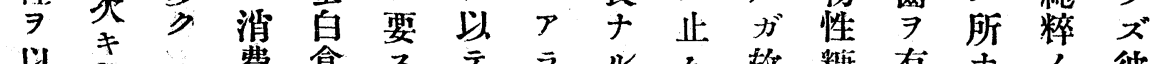

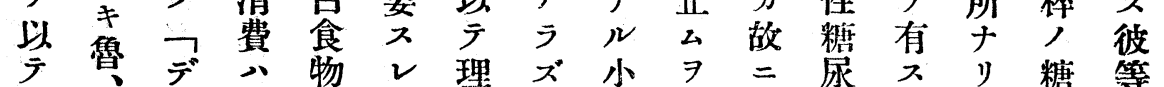

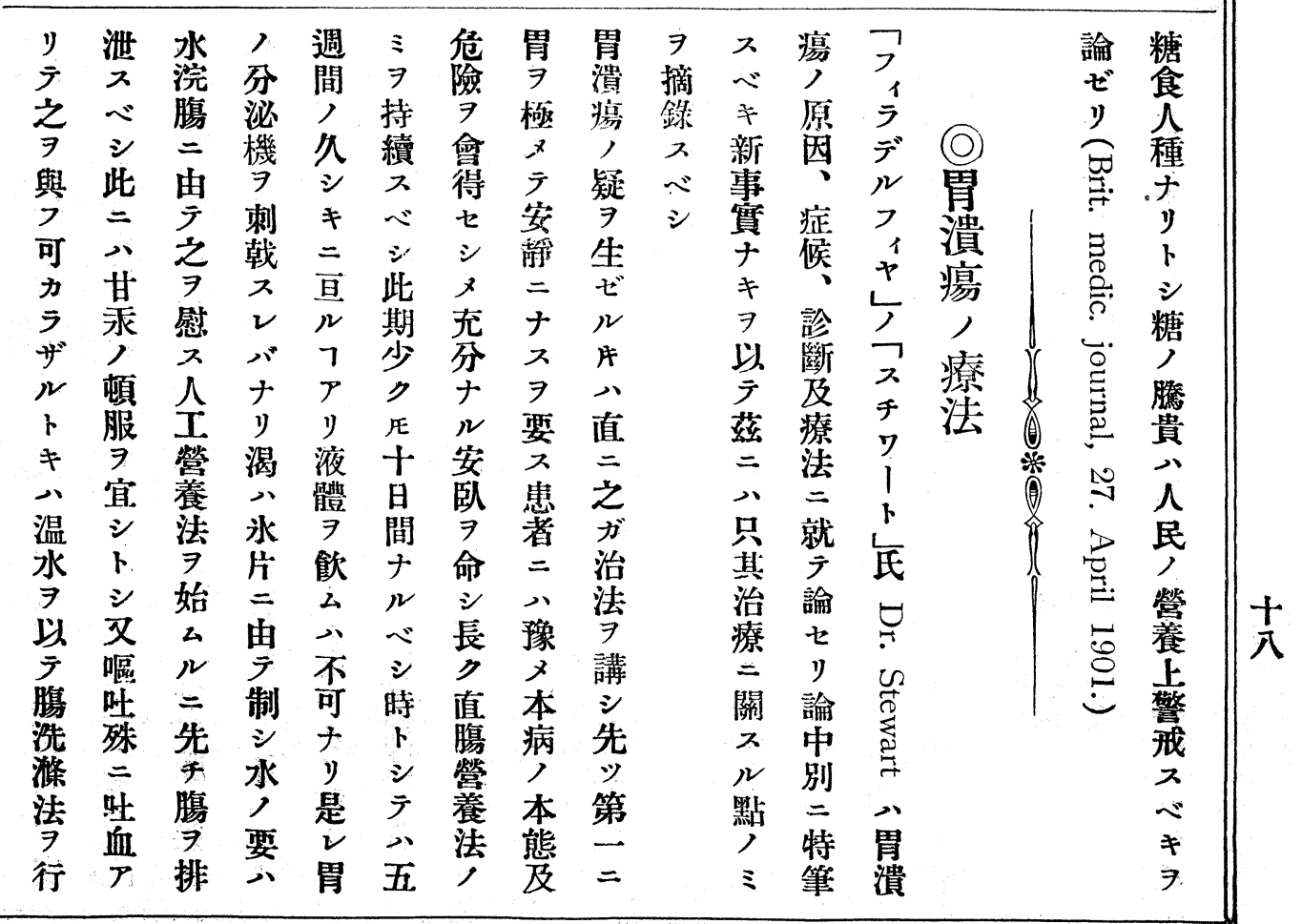




\section{一四○一錄抄誌雜會究研事醫堂天順}

(a)

兽

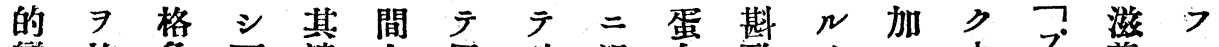

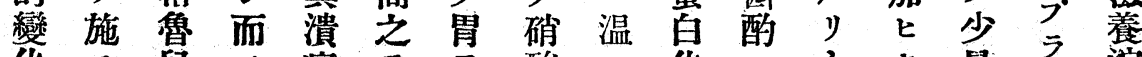

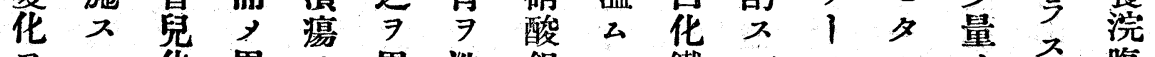

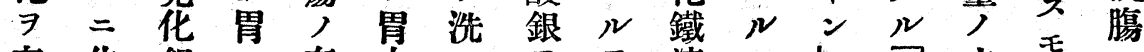

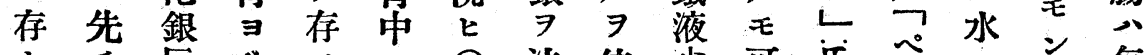

七千居 y ス

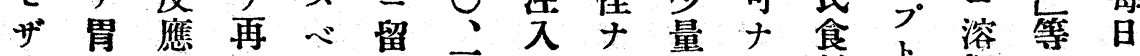

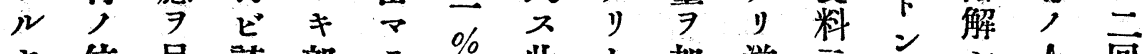

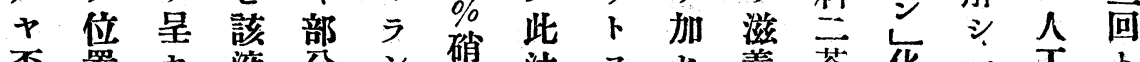

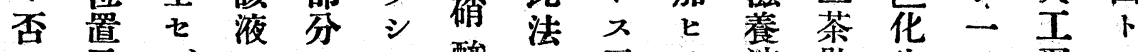

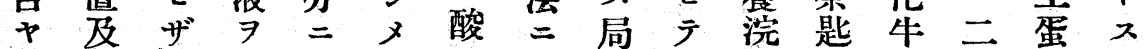

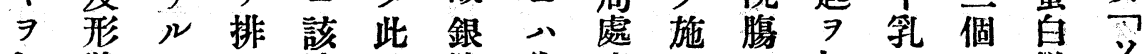

知 狀 = 泄液 時液 先療 $ᄌ$ 一 加一, 滋?

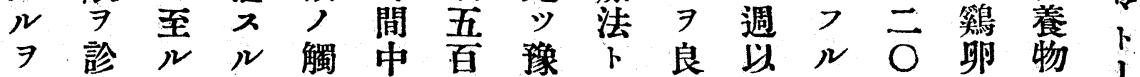

要 香 $\checkmark=N$ 死

文

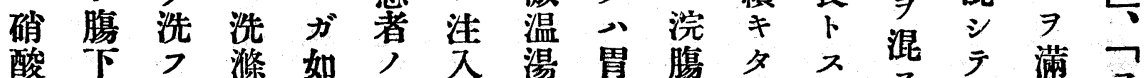

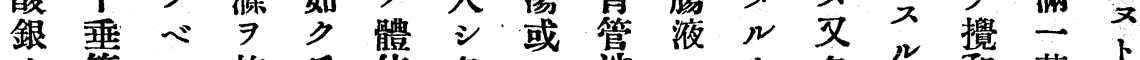

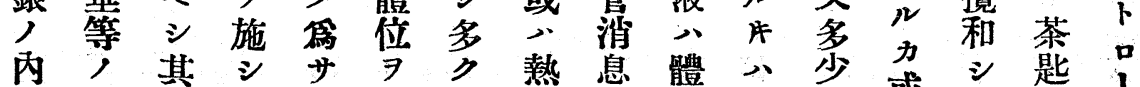

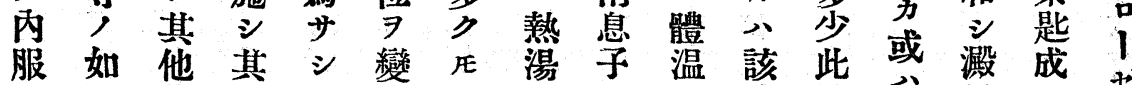

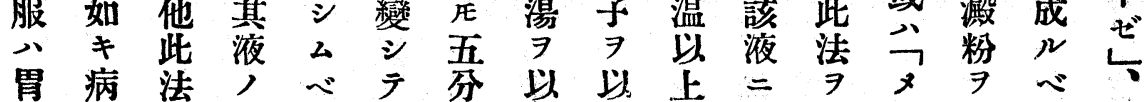

》無 痛 子 $=$ ノブ 亞 $シ$ 痛茶二然量持過》

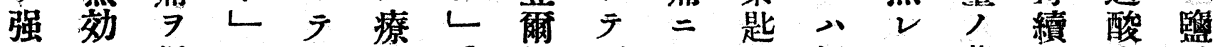

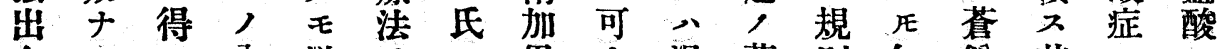
血 $心$ 内滋 $\ni$, 里

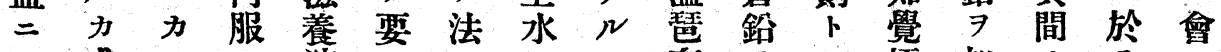
$\therefore$ 或 $ラ 八$ 浣 $三 人$ 布

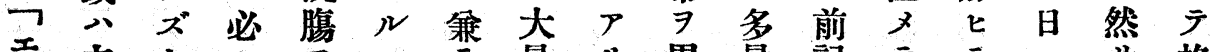

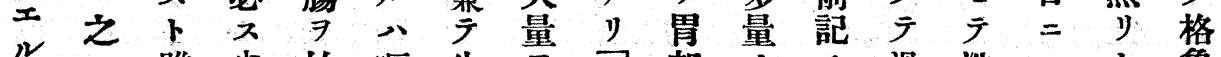

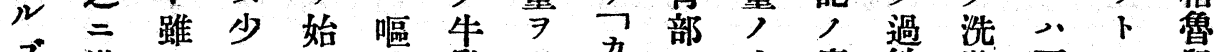

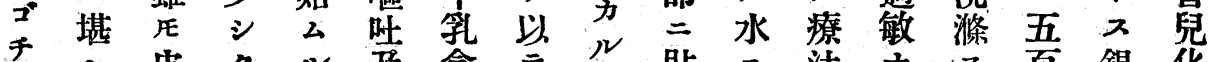

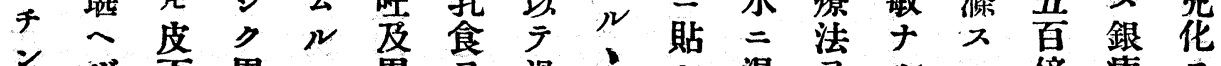

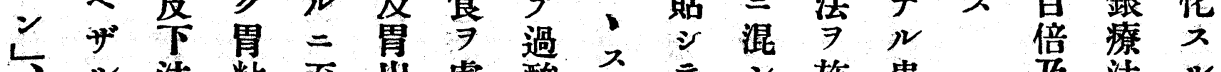

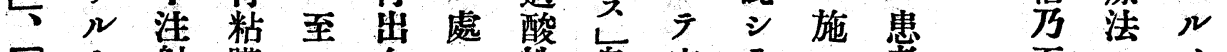

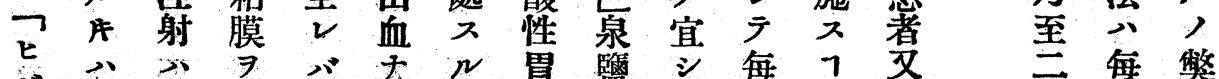

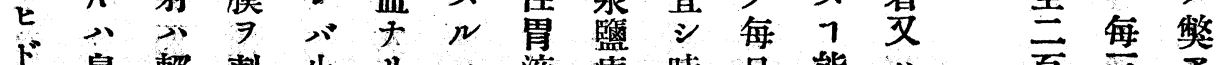

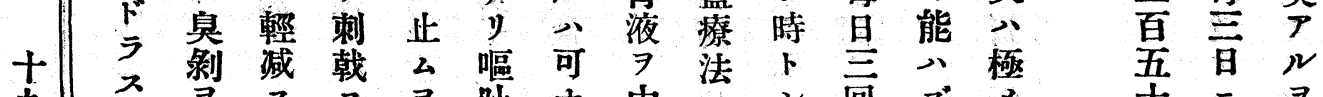

ス $\exists$ ス 7 姓

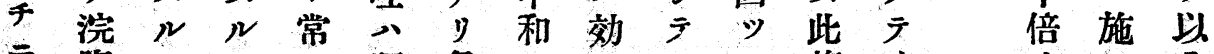

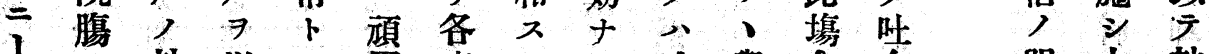

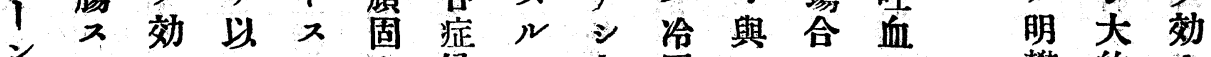

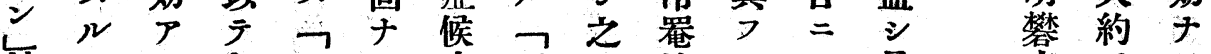

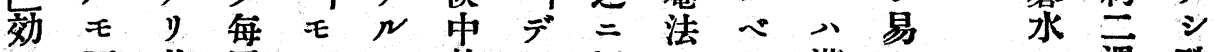

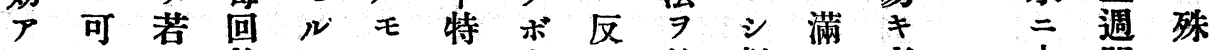

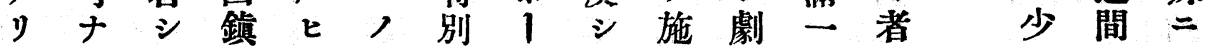


號成十四百三第誌雜會究研事醫堂天順 二四○一

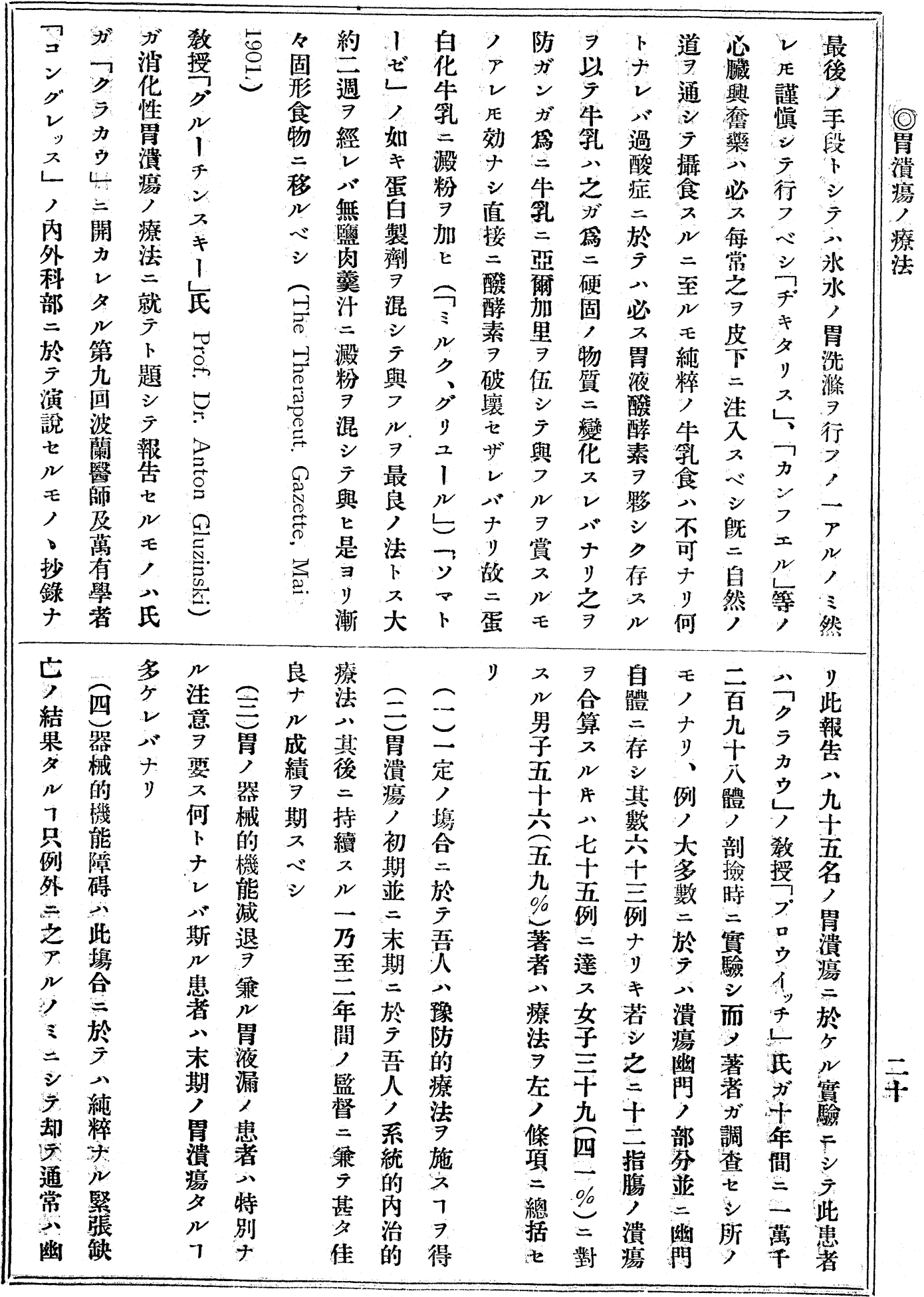


三四0- 録抄誌稚會究研事醫堂天順

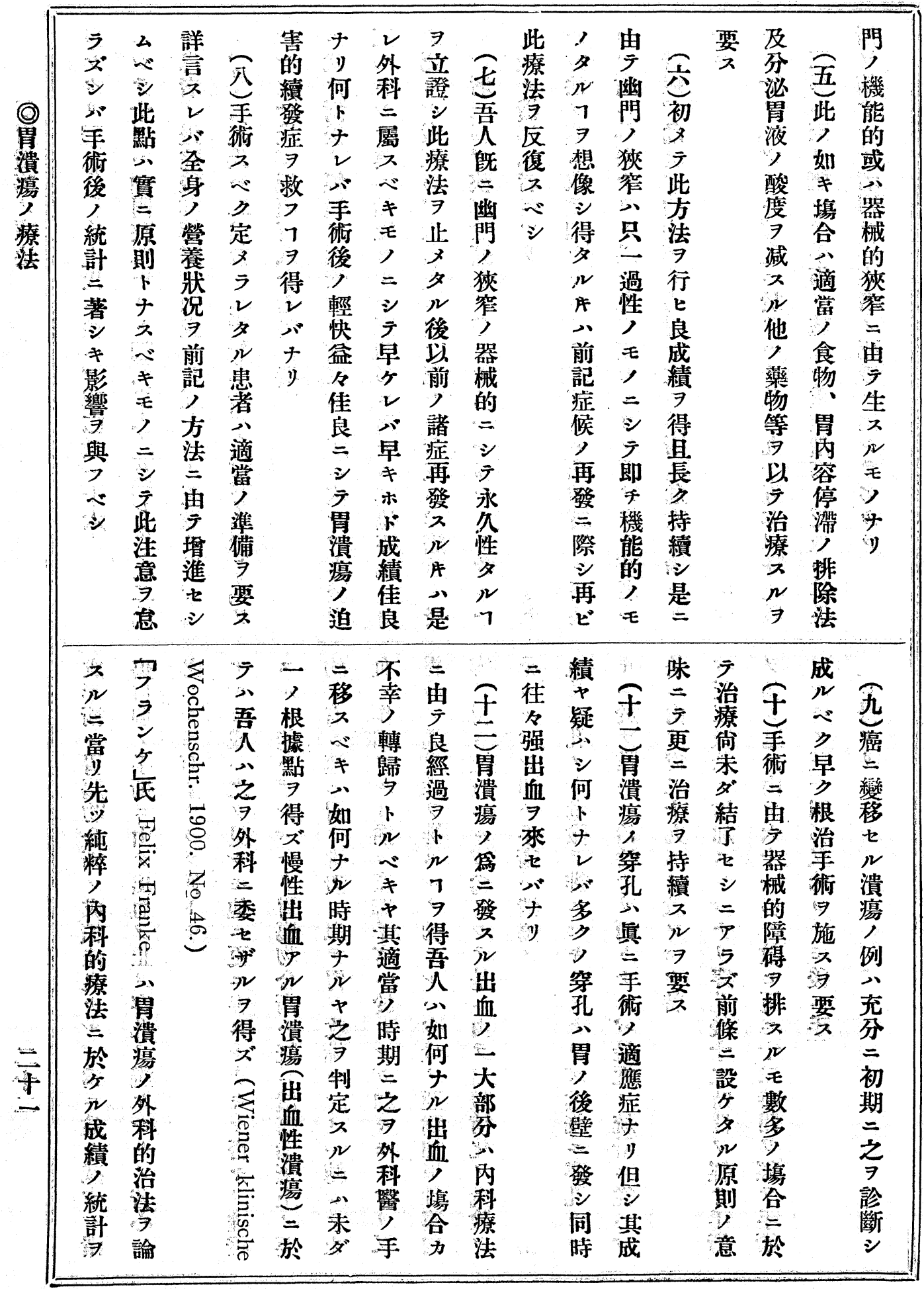


號八十四百三第誌雜會究研事醫堂天順 四四○一

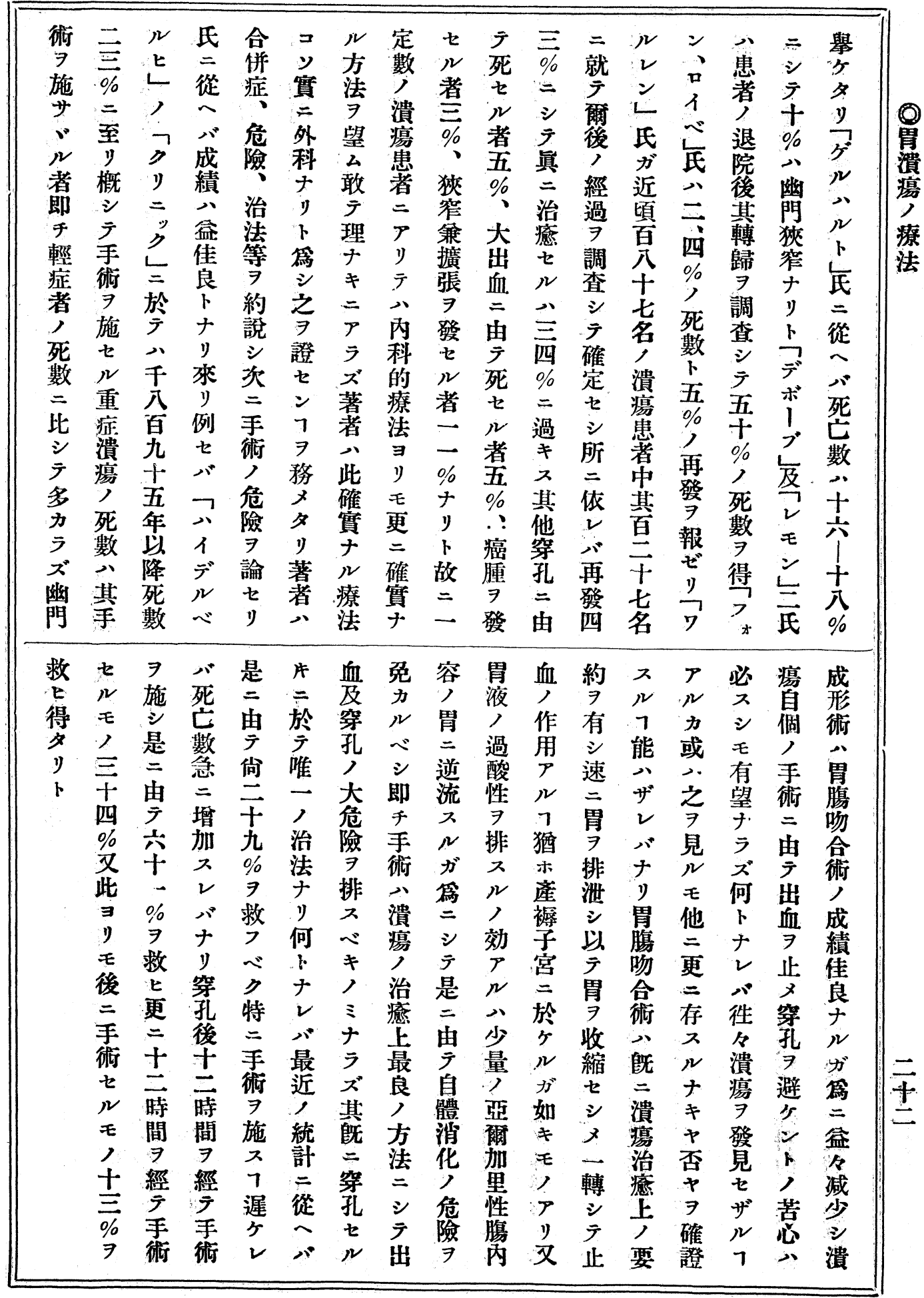


تt四0- 錄抄誌雜會㠰研事醫堂天順

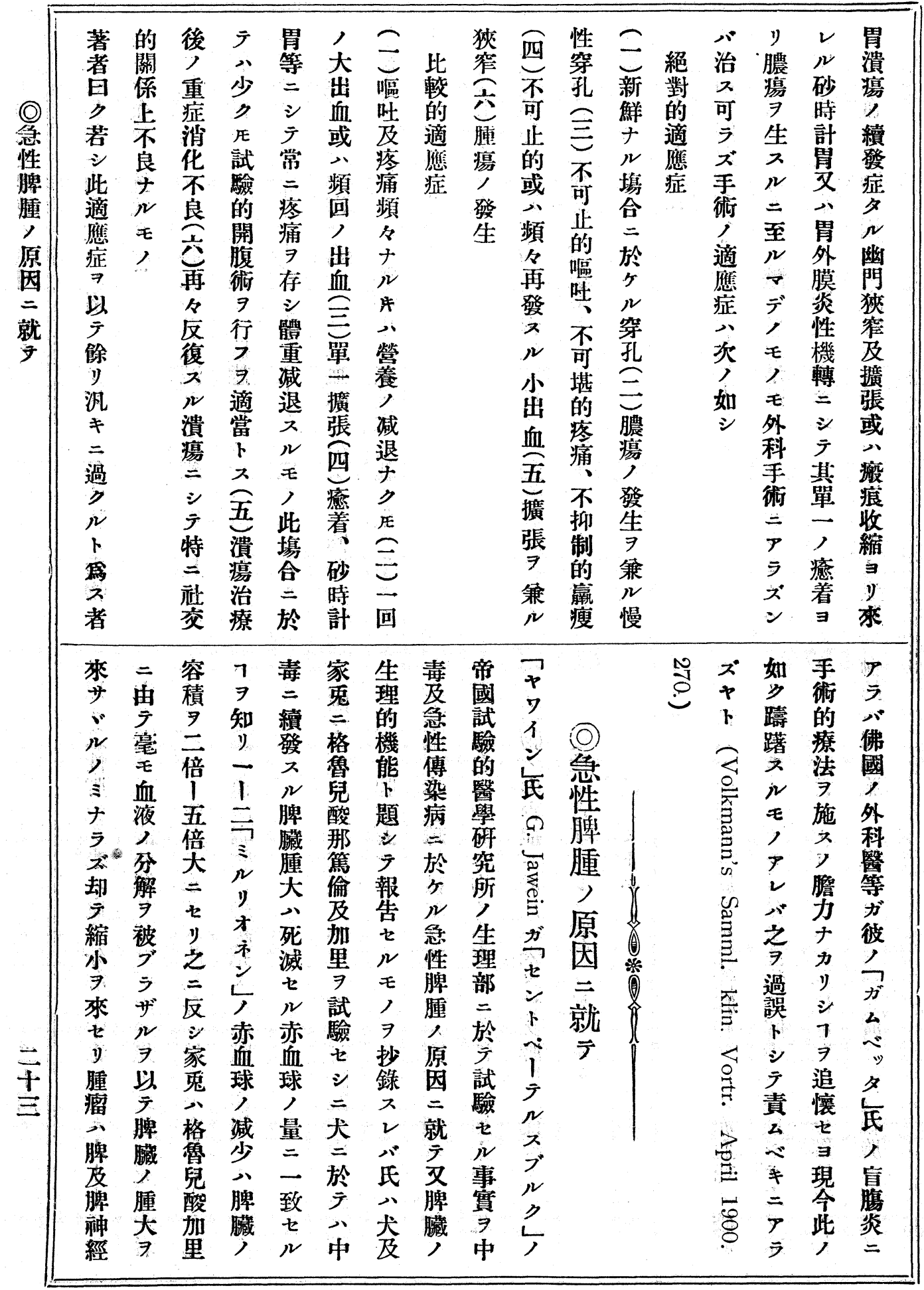


號八十四百三第誌雜會究研事醫堂天順 六四O-

\begin{tabular}{|c|c|c|c|c|c|c|c|c|c|c|c|c|c|c|c|c|}
\hline & 其 & 滅 & 伤 & r & $=$ & $N$ & $\frown$ & s & $p$ & 質 & 同 & Z & $=$ & 合 & 對 & 1 \\
\hline$\equiv$ & 中 & t & 作 & $\Xi$ & $\overline{\bar{\gamma}}$ & 表 & - & $\begin{array}{l}N \\
\text { 事 }\end{array}$ & $\overrightarrow{\overrightarrow{\text { 中 }}}$ & 細 & 成 & + & 績 & $\overline{=}$ & 주 & 面 \\
\hline 而 & 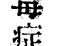 & 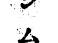 & 雨 & 血 & , & 每物 & 旦 & 番 & 虾 & 中 & 相 & $\begin{array}{l}F \\
11\end{array}$ & 墢 & 证 & 血 & 按 \\
\hline 液 & $=$ & $v$ & 例 & 液 & $\equiv$ & ガ & 種 & 蛋 & 牌 & $=$ & 得 & 双 & $=$ & 疁 & 湾 & 用 \\
\hline 毒 & 於 & $E$ & 之 & 毒 & f & 苏 & 夕 & 左 & 湟 & 集 & 心 & 3 & 充 & 于 & $y$ & $=$ \\
\hline 物 & $\bar{y}$ & 赤 & $\therefore$ & 物 & y & 血 & + & 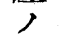 & $\Rightarrow$ & 積 & $\eta$ & 1 & 血 & $y$ & 抗 & 由 \\
\hline$=$ & 毫 & 血 & 7 & $=$ & $\neq$ & 球 & $N$ & 如 & 生 & ᄌ & 即 & 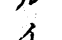 & 及 & 1 & 抵 & $\bar{\gamma}$ \\
\hline 因 & $E$ & 球 & 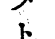 & シ & & 7 & 毒 & シ & ᄀ. & 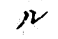 & チ & 1 & 成 & ス & タ & 生 \\
\hline ג & 急 & 自 & 2 & テ & & 破 & 物 & & 长 & 卜 & 血 & & 形 & 脾 & $M$ & $\pi$ \\
\hline$\pi$ & 性 & 體 & モ & 赤 & & 培 & J & & ガ & 脾 & 管 & 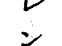 & 過 & 尾 & 各 & $N$ \\
\hline 中 & 脾 & 7 & 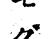 & 血. & & セ & 中 & & 中 & 欌 & $\exists$ & 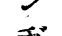 & 多 & $\rightarrow$ & 異 & 者 \\
\hline 毒 & 腫 & 破 & 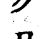 & 球 & & シ & 毒 & & 姜 & 中 & $y$ & 7 & 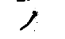 & 其: & F & $=$ \\
\hline 症 & $\exists$ & 壊 & 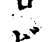 & , & & 牛 & 症 & & $=$ & $=$ & 赤 & $=$ & 狀 & 死 & N & $\gamma$ \\
\hline$=$ & 樉 & 溜 & E & 機 & & $=$ & $=$ & & 關 & 續 & 血 & 3 & 態 & 滅 & $\exists$ & ラ \\
\hline 於 & サ & 滅 & 3 & 能 & & シ & 於 & & ス & 發 & 球 & 1 & $\exists$ & セ & 以。 & $\pi$ \\
\hline $\bar{\gamma}$ & ズ & セ & L & タ & & テ & $\bar{\gamma}$ & & N & 性 & 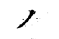 & $L$ & 呈 & $N$ & $\bar{\gamma}$ & シ \\
\hline$\therefore$ & & シ & 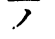 & N & & 即 & II: & & 交 & 刺 & 消 & 急 & ス & 血. & 脾 & テ \\
\hline 血 & & $x$ & 發 & 酸 & & 千 & 急 & & 書 & 戟 & 失 & 以 & N & 球 & 腫 & 各 \\
\hline 液? & & 七 & 生 & 素 & & 專 & 性 & & 当 & 變 & t & $\bar{J}$ & $=$ & $\exists$ & J & 動 \\
\hline 分” & & ザ & 等 & $\Rightarrow$ & & ラ & 脾 & & 獵 & 化 & 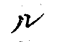 & 試 & 由 & 攝 & 大 & 物 \\
\hline 解 & & $N$ & $=$ & 取 & & I血 & 腫 & & 涉 & 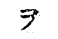 & 割 & 驗 & $\bar{\gamma}$ & y & 小 & 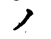 \\
\hline , & & $\varepsilon$ & 由 & 捨 & & 液 & 7 & & シ & 生 & 合 & ス & 生 & 且 & $\therefore$ & 毒 \\
\hline 症 & & Y & $\bar{\gamma}$ & $\pi$ & & 毒 & 見 & & テ & ス & $=$ & ル & ス & \% & 其: & 物 \\
\hline 狀 & & M & 沘 & N & & 物 & タ & & 得 & $N$ & 軟 & $\mathcal{E}$ & N & 更 & 㷪 & $=$ \\
\hline 働 & $\lambda$ & $\exists$ & シ & サ & 症。 & & べ & 中 & & $\sim$ & & 死 & z & $=$ & $=$ & 7 \\
\hline 的 & $\neq$ & $y$ & テ & $v$ & 7 & I & $\neq$ & 贯 & (ิ) & タ & (Im & त & $\nu$ & 於 & 之 & 以 \\
\hline$=$ & 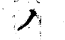 & 承 & 吾 & ה & 件 & 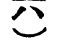 & 毒 & 症 & 艺 & $N$ & 14 & & 力 & $\bar{\gamma}$ & $\exists$ & $\bar{J}$ \\
\hline 腺 & 1 & $\mathcal{N}$ & 1 & 文 & 7 & 慢 & 物 & 例 & 毫 & 牛 & 帟 & & 或 & $\therefore$ & 發 & 急 \\
\hline 細 & 斷 & $モ$ & $\rightarrow$ & 書 & , & 性 & 1 & 之 & $\mathcal{E}$ & > & 血: & & 心 & 毲 & ス & 性 \\
\hline 胞 & 言 & 4 & 中 & $=$ & 時 & 中 & 中 & > & 赤 & 脾 & 球 & & 血 & $\bar{E}$ & 其 & 脾 \\
\hline$\exists$ & z & P & 毒 & 見 & ノ & 毒 & 毒 & 神 & 血 & 腫 & 湼 & & 液 & 脾 & 血 & 腫 \\
\hline$y$ & $v$ & ナ & 症 & $\sim$ & $\Sigma$ & 症 & 症 & 經 & 球 & 去 & $=$ & & 毒 & 腫 & 液 & $\exists$ \\
\hline 保 & 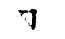 & シ & $=$ & シ & F & $=$ & $=$ & 毒 & ) & $N$ & 死 & & 物 & $\overline{7}$ & 分 & 秝 \\
\hline 存 & 7 & 其 & 於 & 實 & ス & シ & 於 & 物 & 破 & & 減 & & J & 來 & 解 & $\pi$ \\
\hline$t$ & 得 & 分 & 5 & 驗 & & $\bar{\gamma}$ & $\bar{\gamma}$ & $\jmath$ & 壤 & & Ł & & 神 & サ & $\Rightarrow$ & 血 \\
\hline ラ & ベ & 解 & $\mu$ & $\therefore$ & & 牌 & 八 & 中 & $\Rightarrow$ & & ザ & & 經 & ズ & 發 & 液 \\
\hline$v$ & シ & 成 & 稳 & 前 & & 腫 & 末 & 毒 & 棑 & & $N$ & & 系 & 此 & 七 & 分 \\
\hline 以 & 其 & 物 & 性 & 項 & & 7 & タ & 或 & サ & & $=$ & & 又 & 鹪 & ザ & 解 \\
\hline $\bar{z}$ & 他 & $J$ & 脾 & ノ & & 呈 & 曾 & 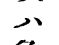 & " & & 至 & & $\rightarrow$ & 合 & $N$ & $\therefore$ \\
\hline 牌 & 赫 & 脾 & 腄 & 試 & & ス & $\overline{\bar{\gamma}}$ & 急 & $\pi$ & & 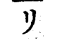 & & 心 & $=$ & $=$ & 中 \\
\hline ノ & 血. & 中 & 7 & 驗 & & N & 脾 & 性 & 毒 & & 身 & & 臟 & 於 & 先 & 毒 \\
\hline 軟 & 球 & $=$ & 以 & $\exists$ & & 八 & 腫 & 胃 & 物 & & 體 & & $=$ & $\bar{J}$ & $F$ & 後 \\
\hline 質 & 1 & 堆 & $\bar{\nu}$ & 確 & & 其: & $\exists$ & 膓 & $=$ & & 酰 & & 作 & $\therefore$ & $\bar{\nu}$ & 慨 \\
\hline 細 & 分 & 積 & 赤 & 證 & & 症 & 記 & 加 & 因 & & $=$ & & 用 & 窐 & 速 & $=$ \\
\hline 胞 & 解 & : & 血 & $\pi$ & & I & セ & 太 & $\pi$ & & 中 & & ス & 息 & $=$ & 宍 \\
\hline$=$ & 產 & $\bar{X}$ & 球 & $N$ & & 急 & $x^{*}$ & 流 & $N$ & & 毒 & & $\Omega$ & $=$ & 死 & 1 \\
\hline 赖 & 物 & 之 & 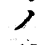 & 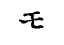 & & 性 & & $\exists$ & 諸 & & 症 & & $=$ & 由 & セ & + \\
\hline 臷 & S) & 7 & 破 & , & & 貧 & & 起 & 般 & & $=$ & & 由 & $\bar{\gamma}$ & $\mathcal{N}$ & $\exists$ \\
\hline$\exists$ & 他 & 秝 & 滅 & $=$ & & 血 & & ス & 7 & & 堪 & & $\bar{\gamma}$ & 死 & 者 & 1 \\
\hline
\end{tabular}




\section{七四O一錄抄誌雜會究研事醫堂天順}

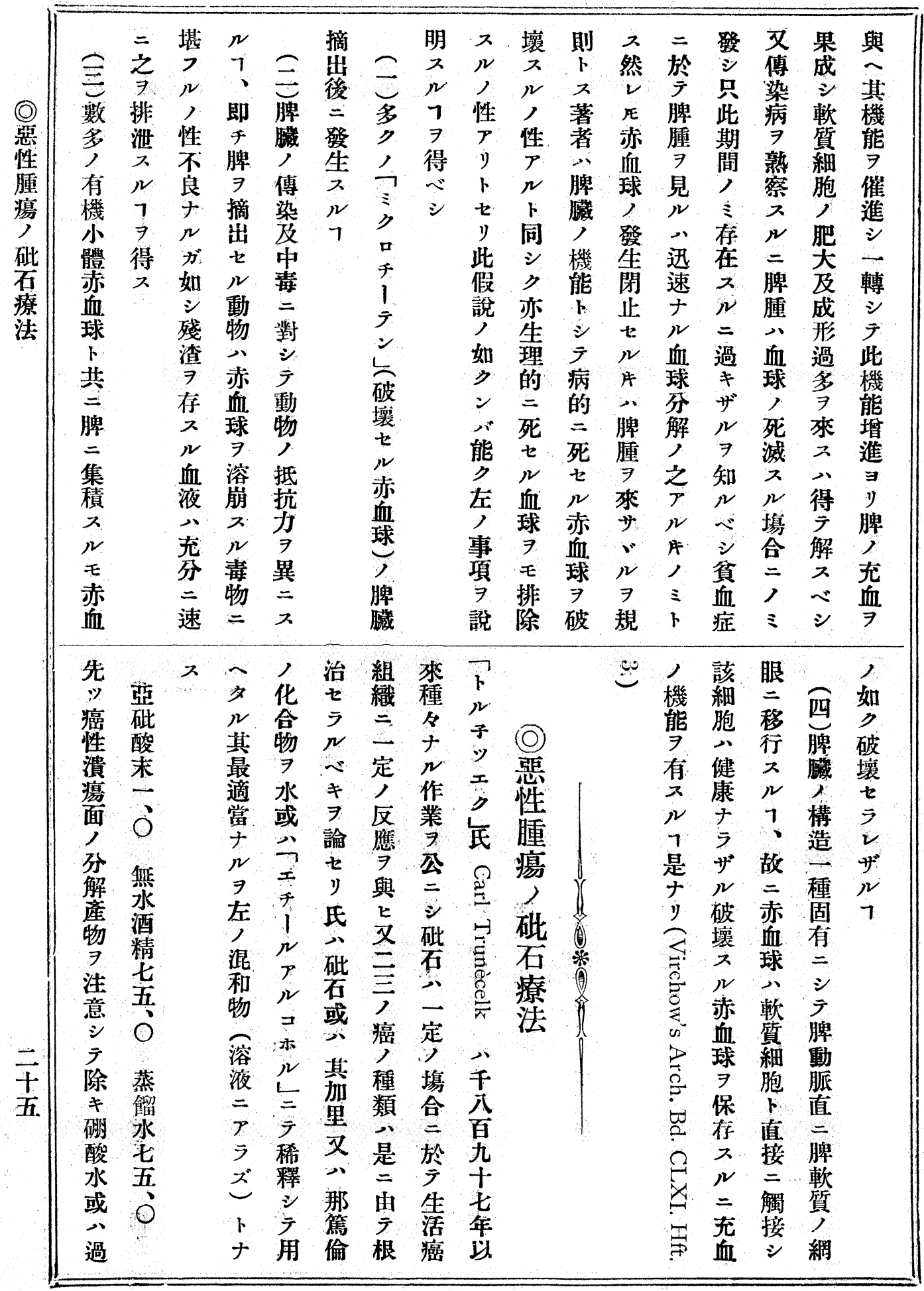


號八十四百三第誌雜會究研事醫堂天順

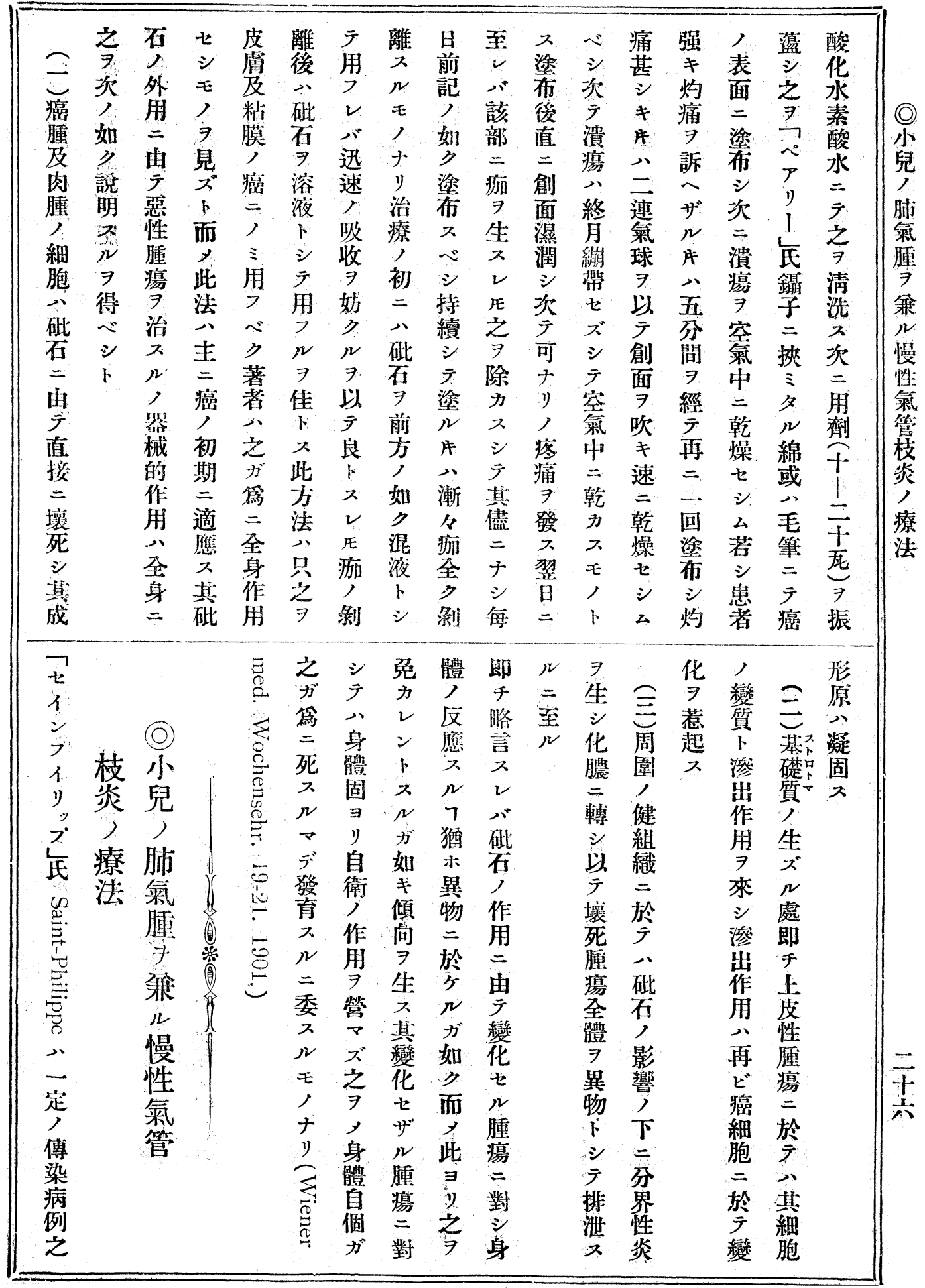


九四○一錄抄誌雜會究研事醫堂天順

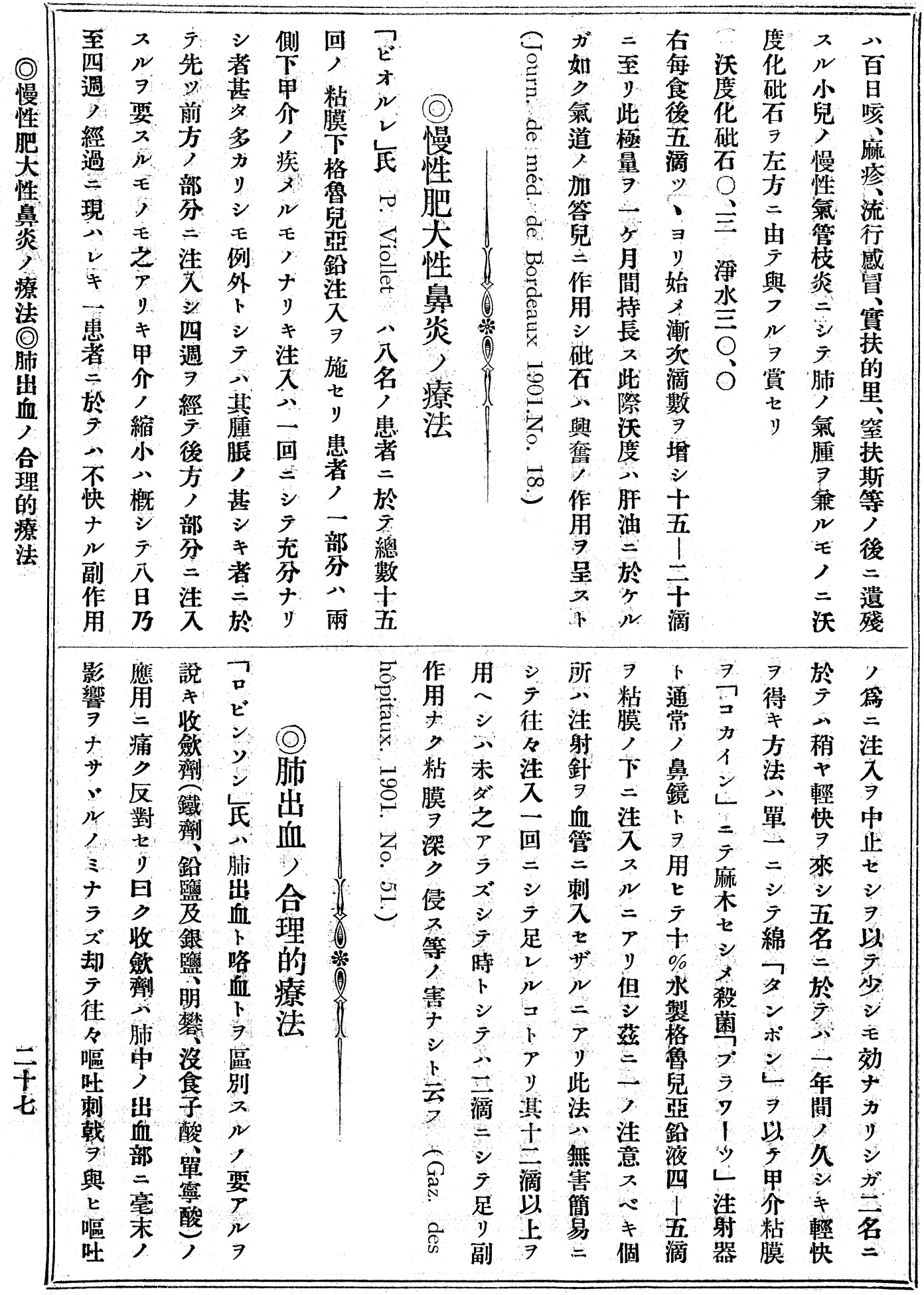




\section{號八十四百三第誌雜會呪研事醫堂天順 O五O-}

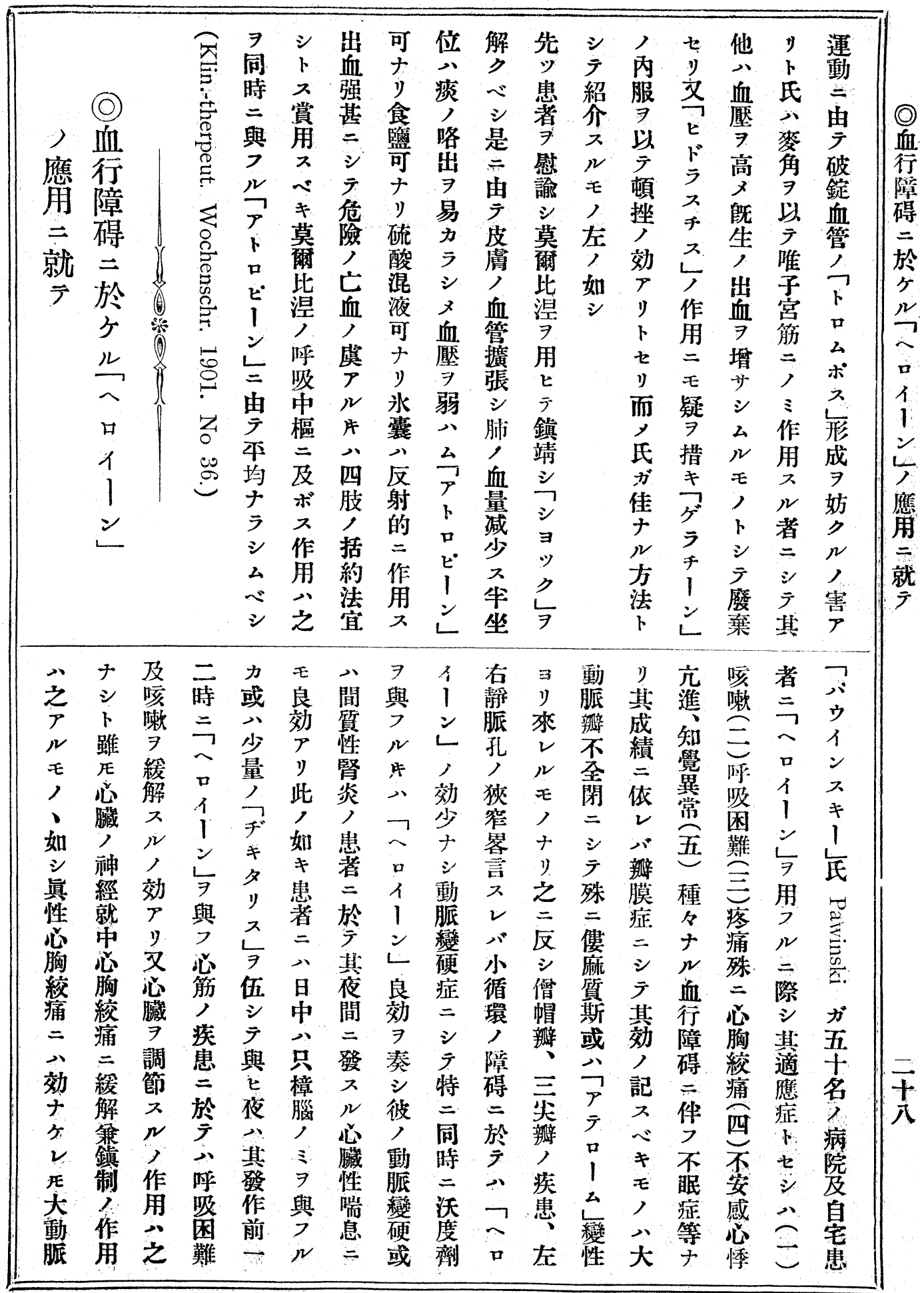




\section{一五O一錄抄誌雜會究研事醫堂天順}

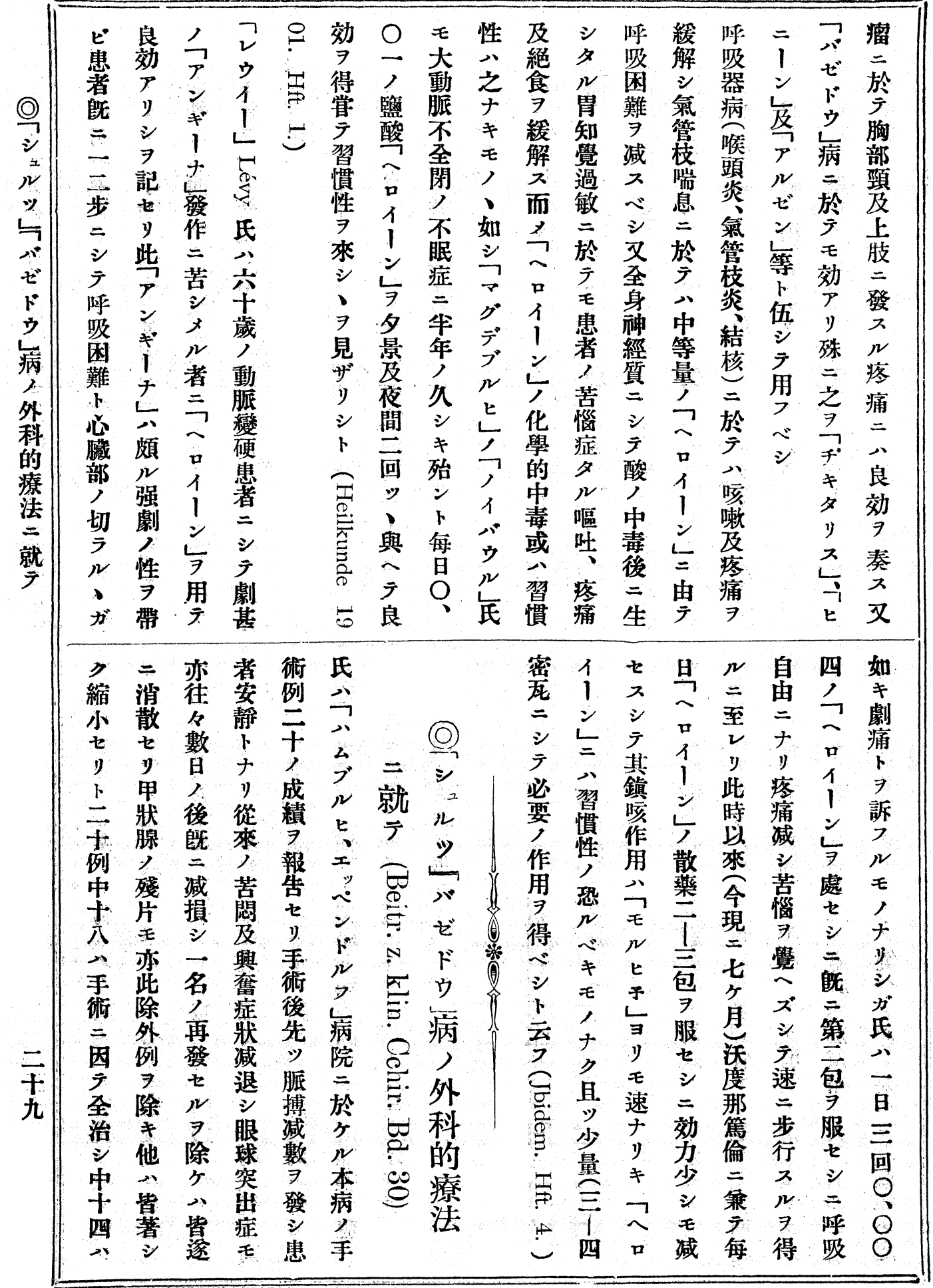


號入十四百三第誌雜會焭研事醫堂天順 二五O-

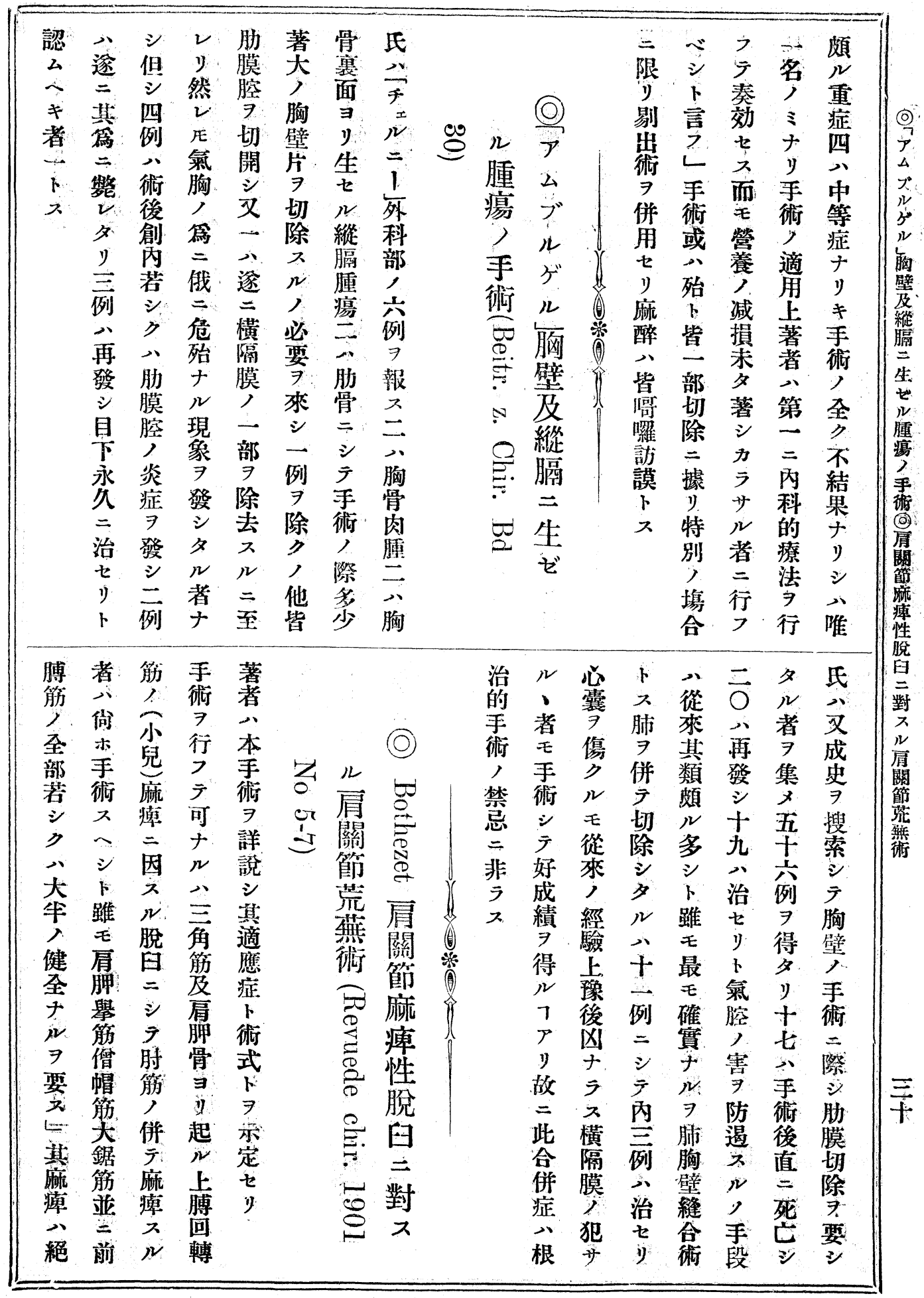


三五－－錄抄誌雜會究研事醫堂天順

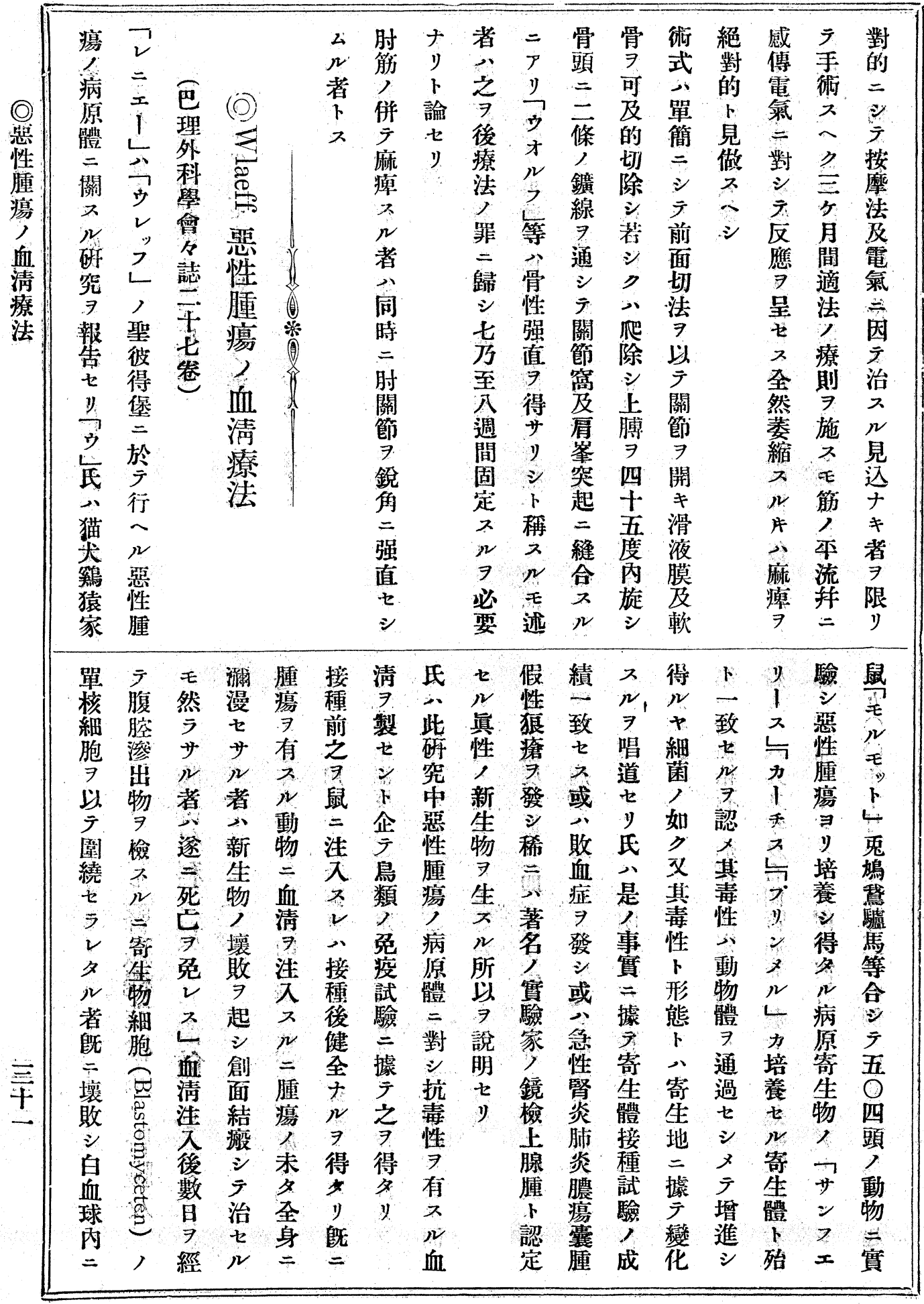


號入十四百三第誌雉會究研事醫堂天順 四五O一

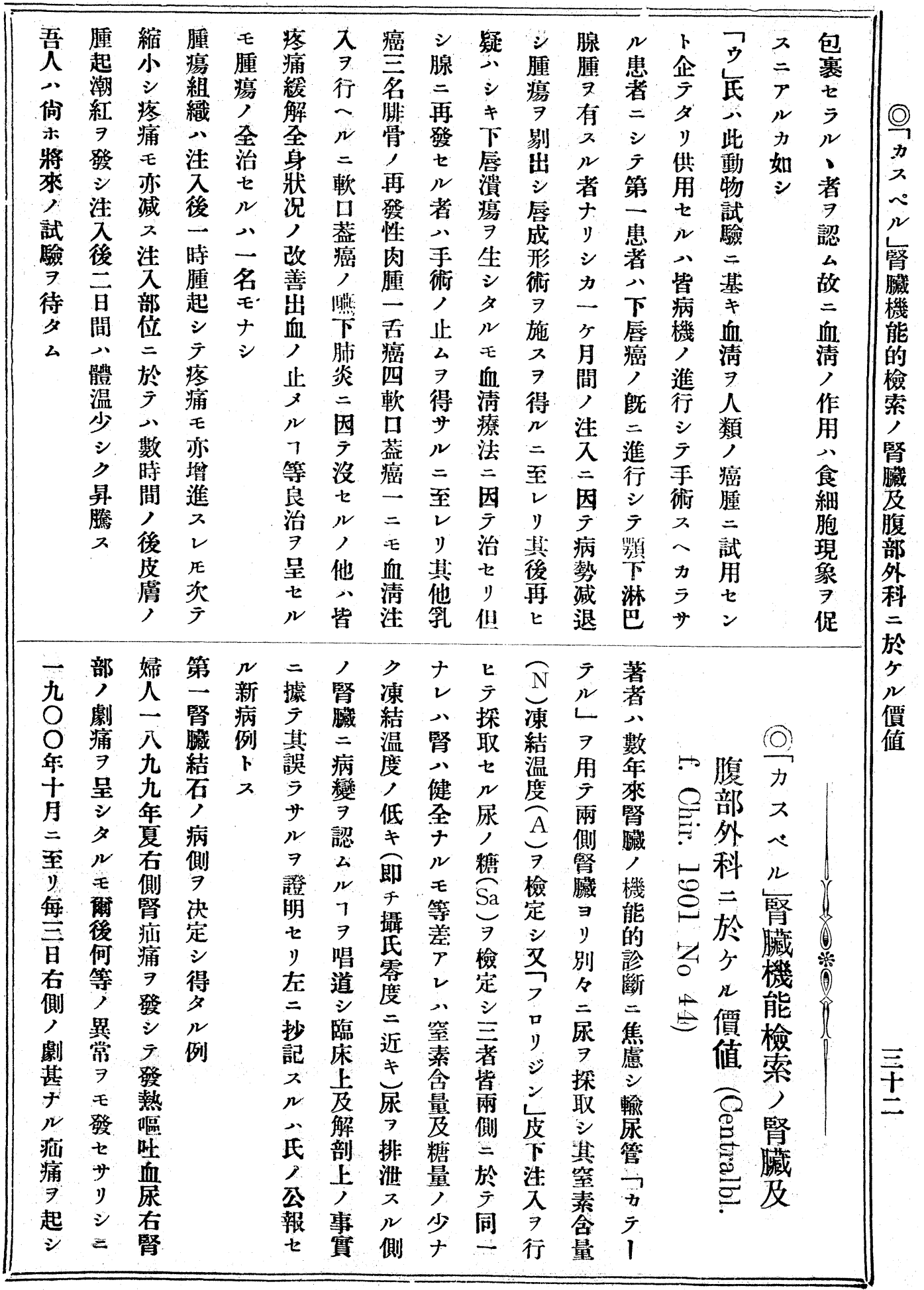




\section{五五0- 錄抄誌雜會究研事醫堂天順}

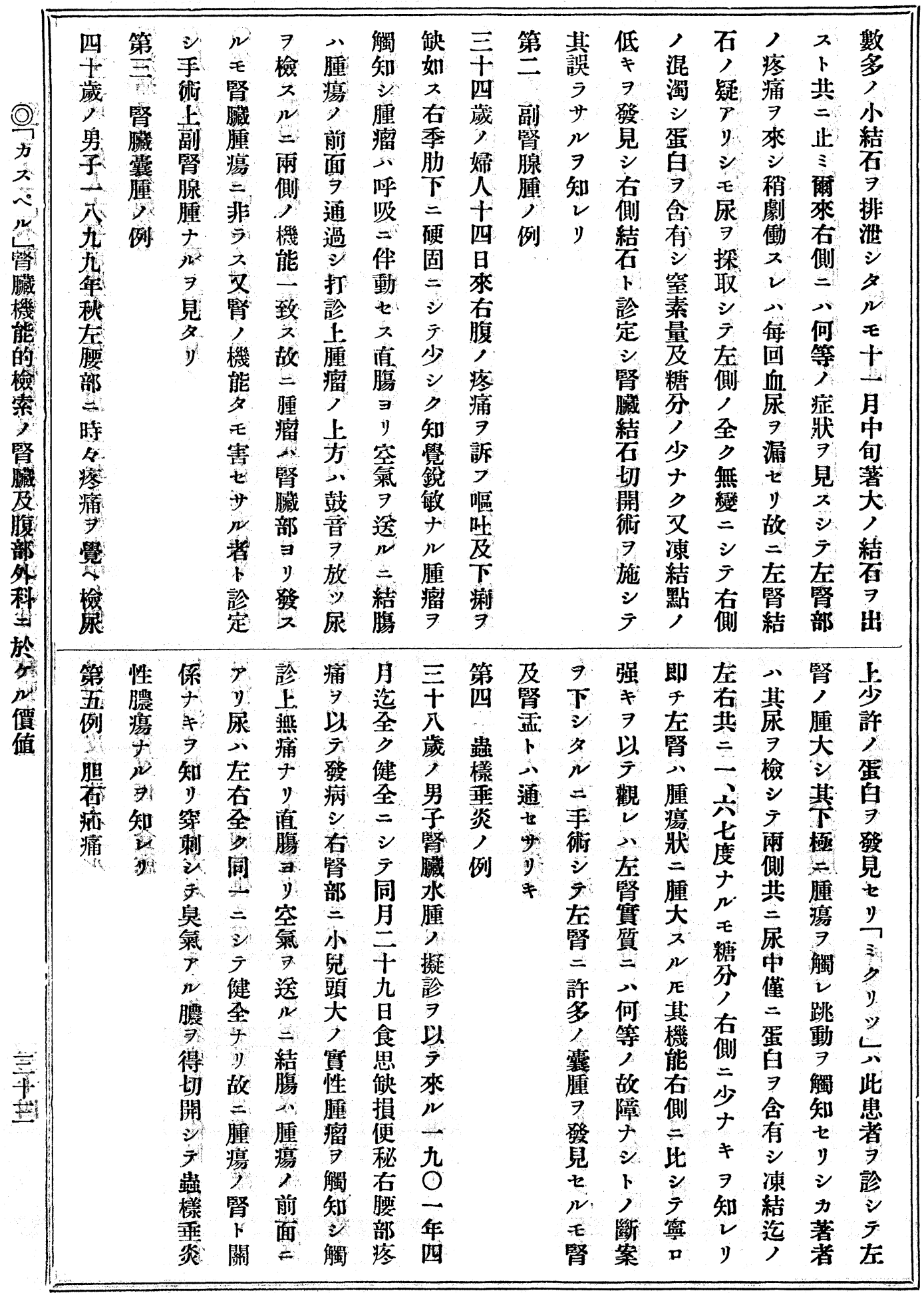


號八十四百三第誌雜會究研事醫堂天順 六五O一

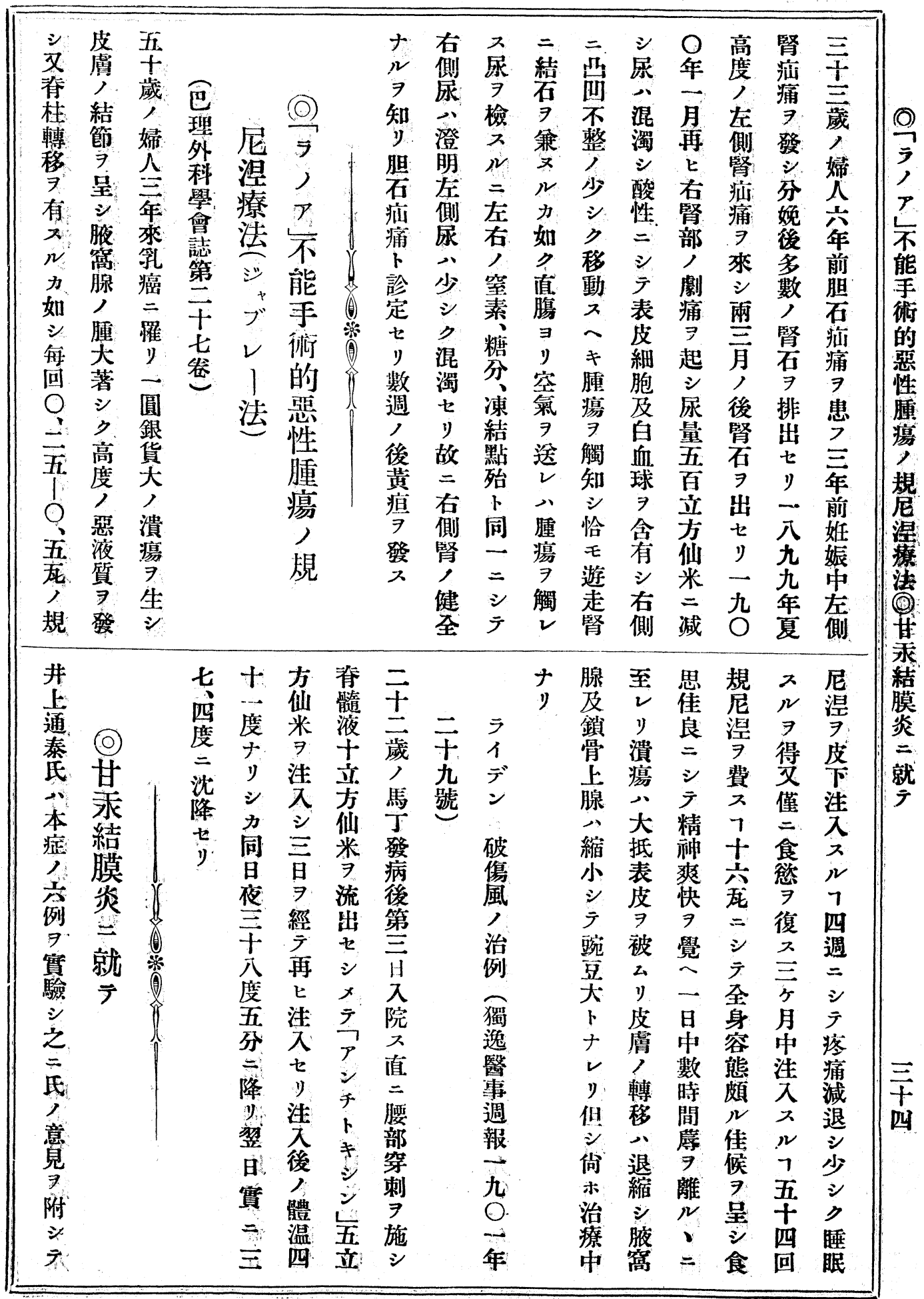


七五○一錄抄誌權會究研事醫堂天順

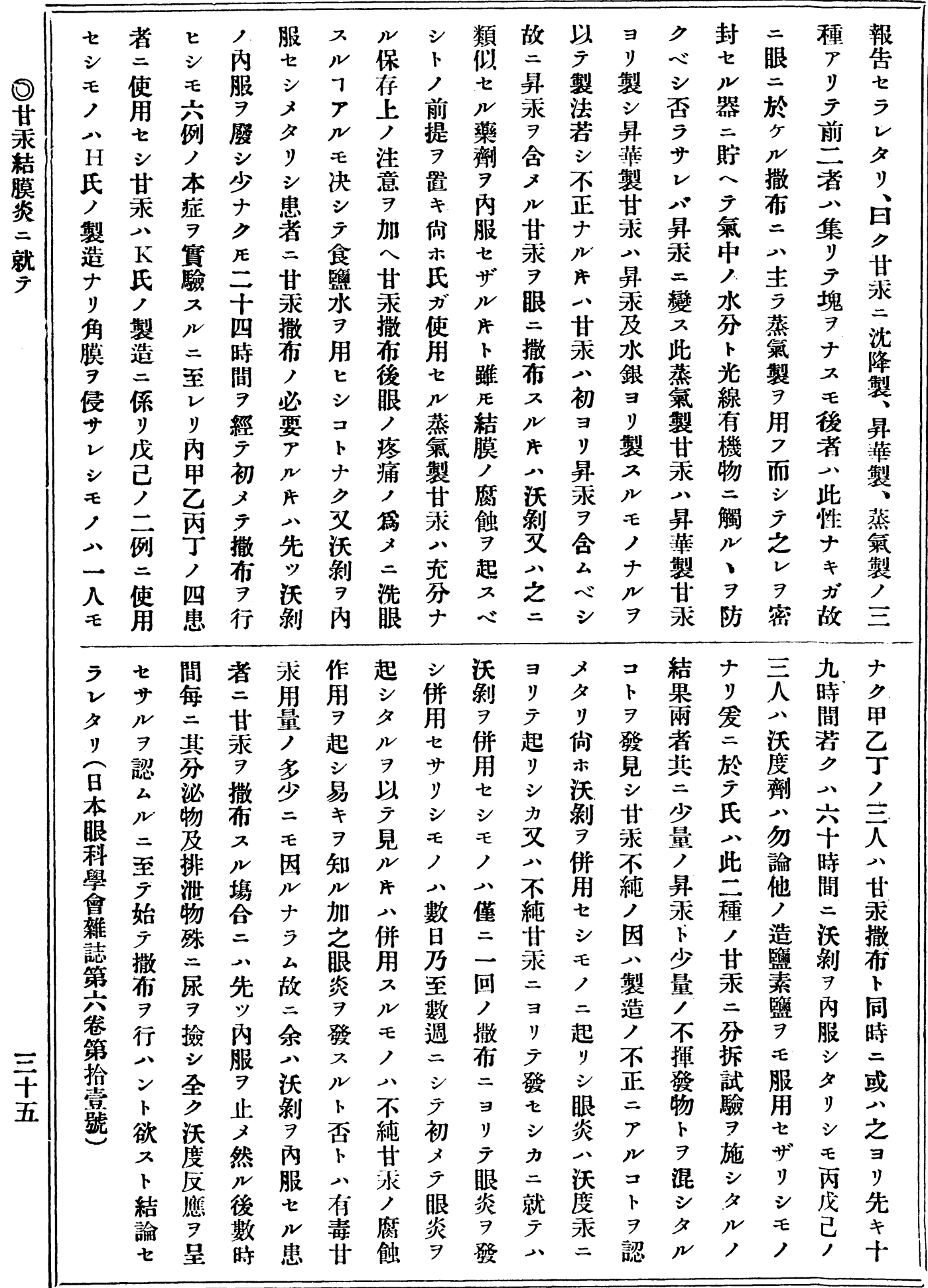


號八十四百三第誌雜會究研事醫堂天順 入五O一

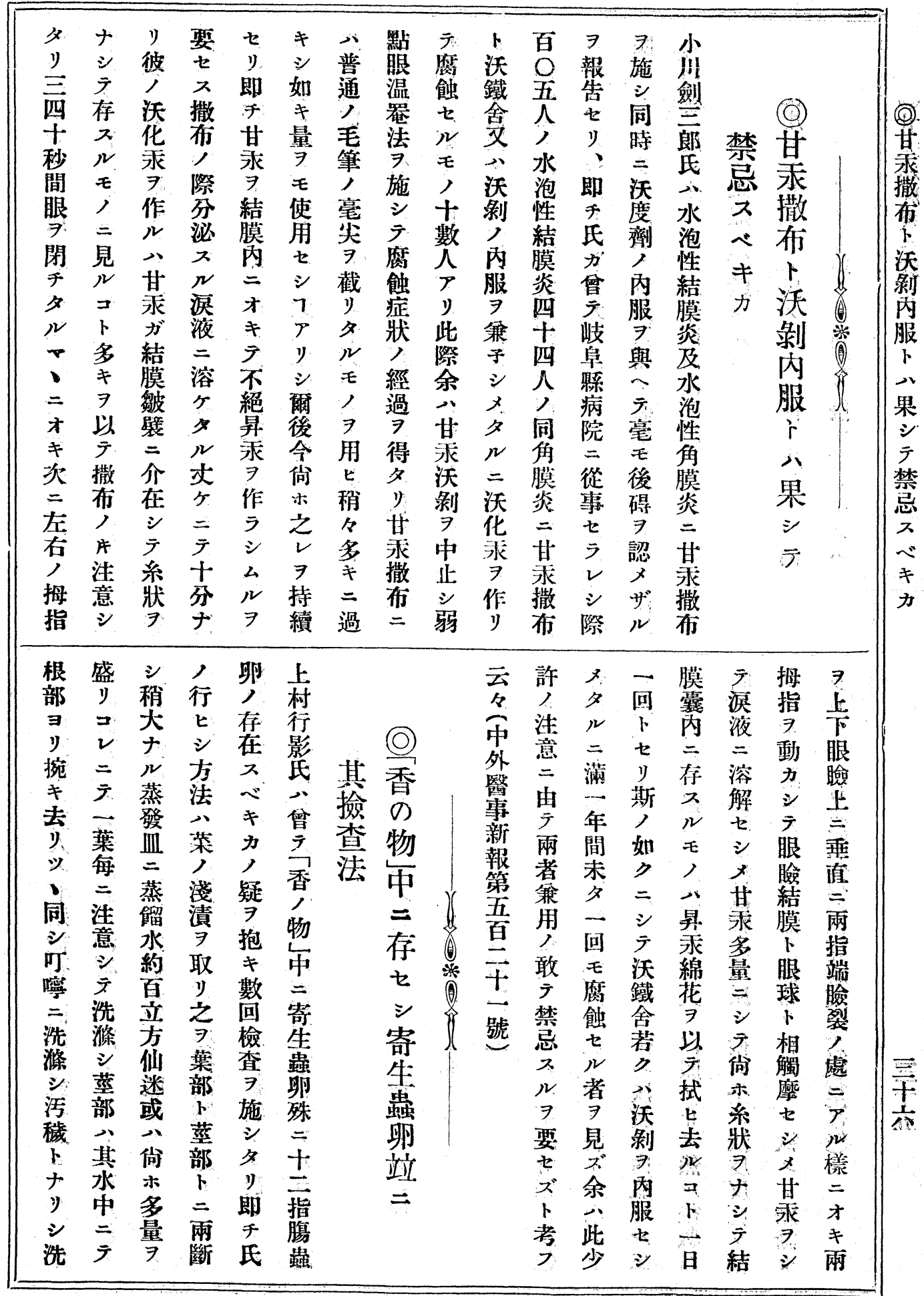




\section{九五O- 錄抄誌雜會究研事醫堂天順}

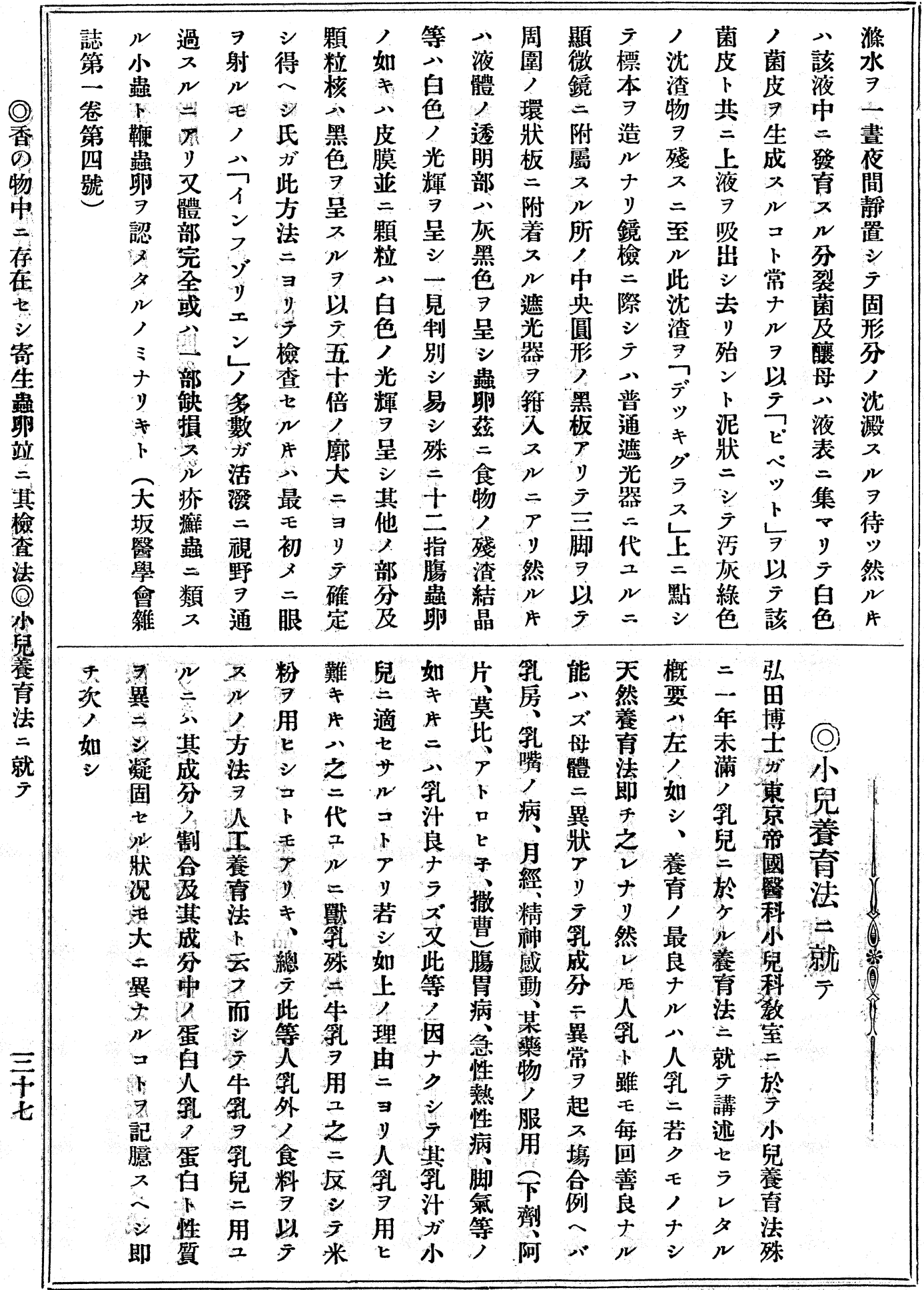


躆八十西百三第誌雜會究研事醫堂天順 O卡O-

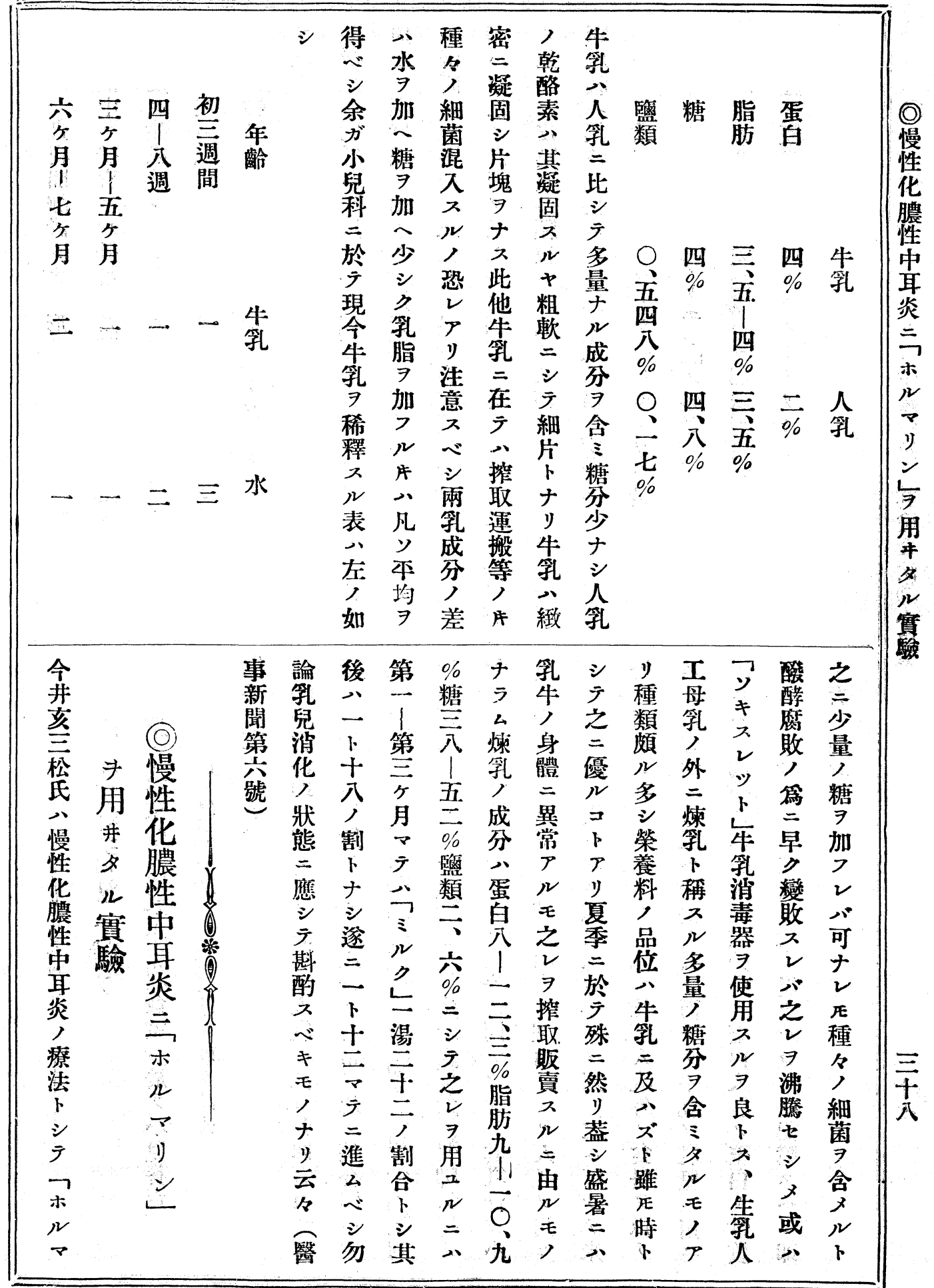




\section{一共口一錄抄誌㱷會觉研事醫堂天順}

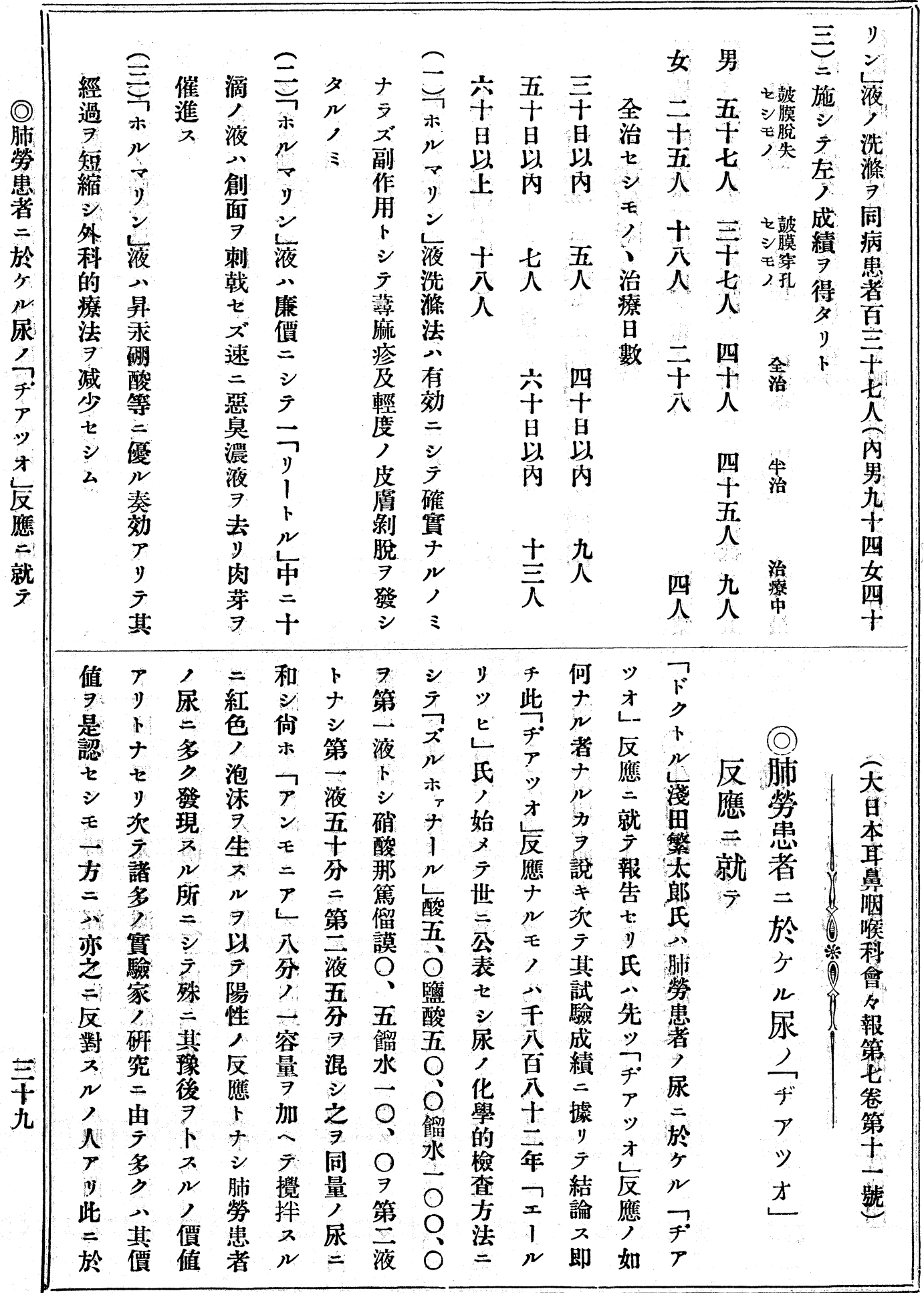


號入十四百三第誌雜會究研事醫堂天順 二坴O-

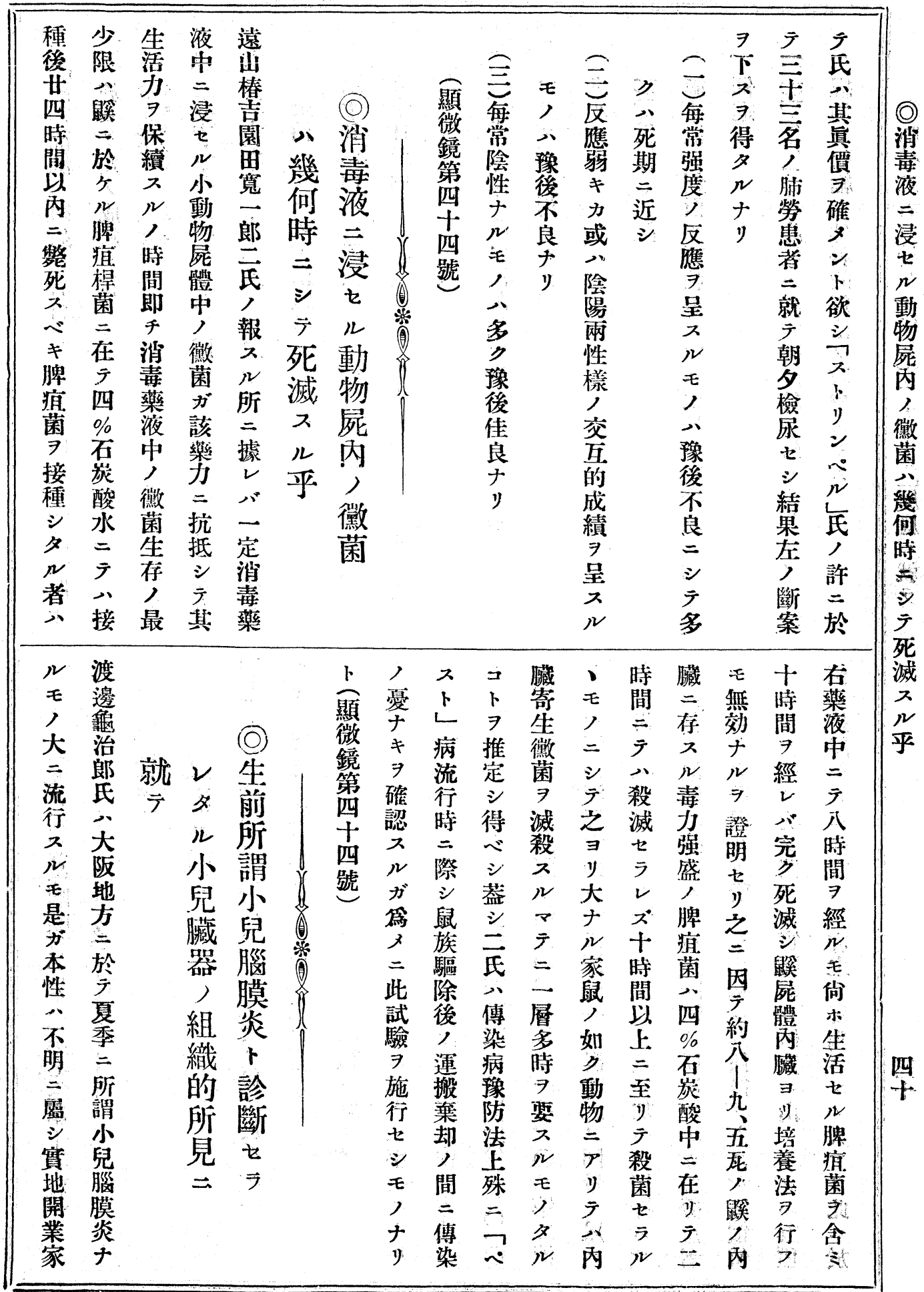


三六口一錄抄誌雜會笲研事醫堂天順

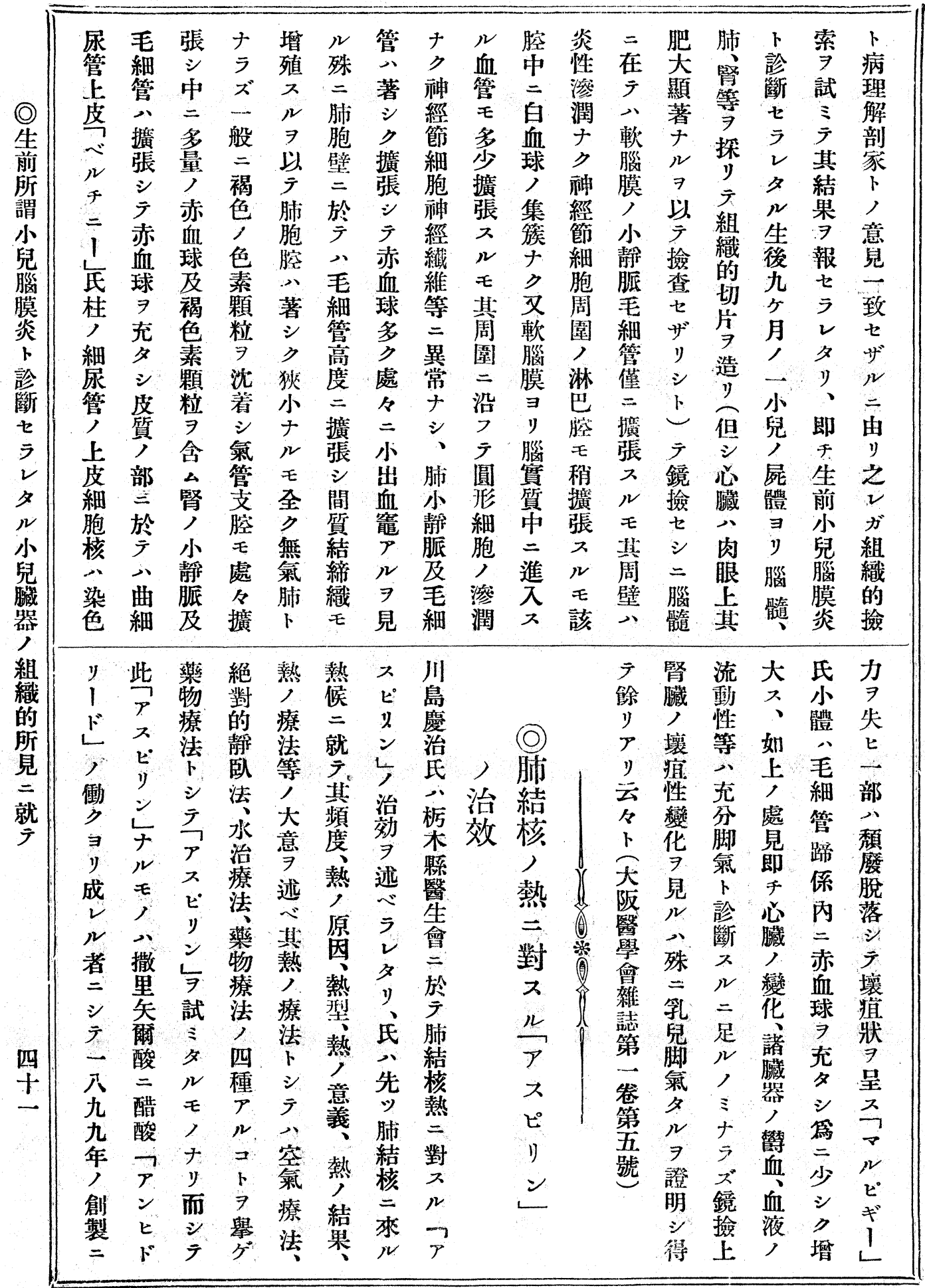


號八十四百三第誌雜會笲研事醫堂天順 四六O-

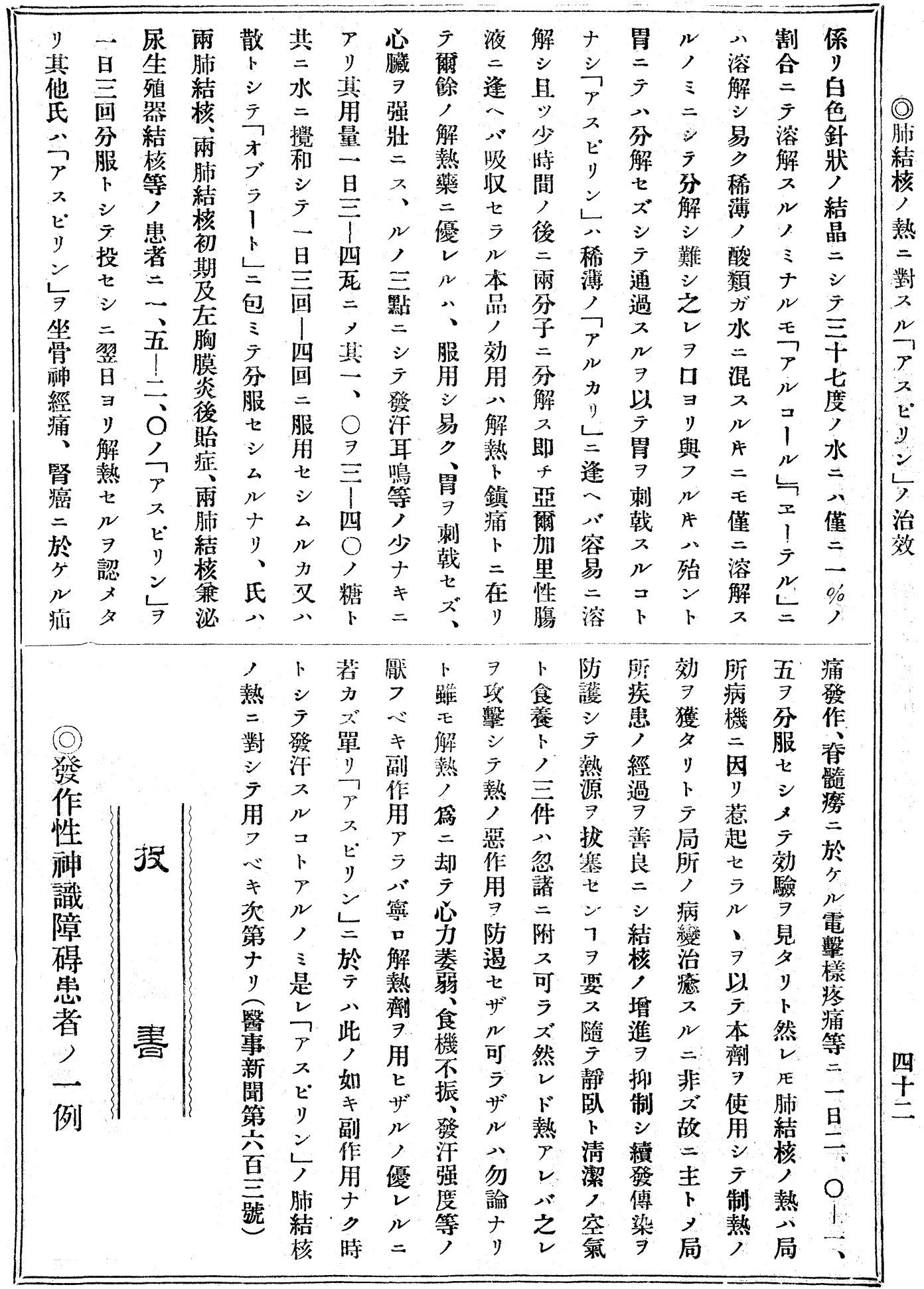

